\title{
Achieving the Millennium Development Goals in Sub-Saharan Africa
}

\author{
A Macroeconomic Monitoring Framework
}

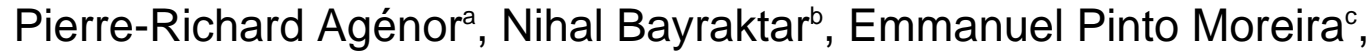 \\ and Karim El Aynaouid
}

\begin{abstract}
This paper presents an integrated macroeconomic approach to monitoring progress toward achieving the Millennium Development Goals (MDGs) in Sub-Saharan Africa. At the heart of our approach is a macro model that captures key linkages between foreign aid, public investment (disaggregated into education, infrastructure, and health), the supply side, and poverty. The model is linked through cross-section regressions to indicators of malnutrition, infant mortality, life expectancy, and access to safe water. A composite MDG Indicator is also calculated. The functioning of our framework is illustrated by simulating the impact of an increase in aid and a debt write-off for Niger at the MDG horizon of 2015, under alternative assumptions about the degree of efficiency of public investment. Our approach can serve as the building block of Strategy Papers for Human Development (SPAHD), a more encompassing concept than the current "Poverty Reduction" Strategy Papers.
\end{abstract}

World Bank Policy Research Working Paper 3750, October 2005

The Policy Research Working Paper Series disseminates the findings of work in progress to encourage the exchange of ideas about development issues. An objective of the series is to get the findings out quickly, even if the presentations are less than fully polished. The papers carry the names of the authors and should be cited accordingly. The findings, interpretations, and conclusions expressed in this paper are entirely those of the authors. They do not necessarily represent the view of the World Bank, its Executive Directors, or the countries they represent. Policy Research Working Papers are available online at http://econ.worldbank.org.

${ }^{a}$ Hallsworth Professor of International Macroeconomics and Development Economics, University of Manchester, and co-Director, Centre for Growth and Business Cycle Research; ${ }^{\text {b }}$ Assistant Professor, Penn State University, and World Bank; ' Senior Economist, World Bank; and ${ }^{\mathrm{d}}$ Advisor, Central Bank of Morocco, and World Bank. Many of the ideas presented in this paper were developed in the context of a joint World Bank-United Nations Development Program (UNDP) technical assistance project for Niger. 


\section{Table of Contents}

I. Introduction

II. Methodology

1. The Macro Framework

2. Link with the MDGs

III. Baseline Projections

IV. Policy Experiments

1. Increase in Foreign Aid

2. Cancellation of Foreign Debt

V. Inefficient Public Investment

VI. Conclusions

References

Appendix-Definition of Variables and Cross-Section Regressions

Figures and Tables 
3,000 Africans die every day of a mosquito bite. Can you think about that, malaria? That's not acceptable in the 21st century and we can stop it. And water-borne illnesses--dirty water takes another 3,000 lives--children, mothers, sisters... If we're to take this issue seriously, and we must, because in 50 years, you know, when they [G-8 Heads of State] look back at this moment... they'll talk about what we did or didn't do about this continent bursting into flames. It is the most extraordinary thing to watch people dying three in a bed, two on top and one underneath, as I have seen in Lilongwe, Malawi. I mean, it is an astonishing thing. And it's avoidable. It's an avoidable catastrophe. You saw what happened with the tsunami. You see the outpouring, you see the dramatic pictures. Well, there's a tsunami happening every month in Africa, but it's an avoidable catastrophe. It is not a natural calamity.

Bono, Lead singer of U2, on NBC's Meet the Press (June 16, 2005).

\section{Introduction}

In May 1996, development ministers from the member countries of the OECD Development Assistance Committee (DAC) issued a report, Shaping the $21^{\text {st }}$ Century: The Contribution of Development Co-operation, in which they presented their vision for development progress into the next century. They formulated a strategic framework aimed at achieving seven goals set up mainly to promote social development and combat widespread poverty in low-income countries (LICS). Subsequently, the need to monitor and report on progress toward the goals resulted in the establishment of quantified targets for each goal and the setting of indicators for measuring progress. The publication of the report A Better World for All: Progress toward the International Development Goals in June 2000 formally paved the road for a monitoring process of the Millennium Development Goals (MDGs).

In September 2000, during the United Nations (U.N.) Millennium Summit, the international community adopted the Millennium Declaration and the MDGs as strategic indicators by which poor countries and the donor community could measure progress toward reducing poverty and improving key dimensions of development. LICs were called on to adopt the MDGs in the context of their Poverty Reduction Strategy Paper (PRSP) and monitor progress toward meeting the goals. In March 2002, at the International Conference on Financing for Development in Monterrey, Mexico, the international community established a 
framework for global partnership between developed and developing countries to combat widespread poverty around the world. Later that same year, at the World Summit on Sustainable Development in Johannesburg, South Africa, U.N. member states reaffirmed their commitment to meeting the MDGs.

However, recent assessments of the status of the MDGs in LICs reveal that progress in achieving them has been mixed and slow. In its report published in January 2005, the Millennium Project (developed under the auspices of the United Nations) noted that although several countries are on track to achieve some of the goals, many others are falling way short-particularly so in SubSaharan Africa. The report issued by the Commission for Africa (2005) in March 2005, and the more recent reviews of progress toward achieving the MDGs by the United Nations (2005) and the IMF and the World Bank (2005b), also provide a bleak picture for the region.

Several of these recent reports have recognized that growth is a key requirement for improving living standards in Sub-Saharan Africa, and emphasized the need for a "big push" in public investment in education, health and infrastructure in order for African countries to meet the MDGs. Many PRSPs in the region have recognized the role that infrastructure can play in stimulating growth, particularly those aimed at improving productivity and reducing production costs in agriculture (see OECD (2004)). The development of transportation networks is also viewed as particularly important for the numerous landlocked countries in the region to stimulate trade-both domestically and internationally. A joint report by the Bretton Woods institutions (see World Bank (2005b)) and the Bank's recent Action Plan for Africa (see World Bank (2005c)) called for a doubling of spending on infrastructure (both for "new" investment and operation and maintenance) in Sub-Saharan Africa, from 4.7 percent of GDP in recent years to more than 9 percent over the next decade, to fill severe gaps in the region. ${ }^{1}$ To finance this big push, and given the limited ability of most

\footnotetext{
${ }^{1}$ How this number is arrived at is, however, not entirely clear.
} 
countries in the region to raise domestic resources through taxation or borrowing, donors have been called upon to provide massive debt relief and scale up considerably their official development assistance. ${ }^{2}$

A key issue therefore for LICs is to examine how debt relief and increases in aid affect the MDGs, and account for these effects in designing their poverty reduction strategies. Understanding these effects, and quantifying them, is also important for donors to enhance the quality and depth of the policy debate. Indeed, the need to strengthen the quality of technical assistance to countries involved in the PRSP process is widely recognized by development institutions (see World Bank (2002, 2004, 2005a)) and other observers. Unfortunately, current thinking on how to achieve the MDGs has largely failed so far to provide a tractable quantitative macroeconomic framework that captures key linkages between foreign assistance, the composition of public investment, and the supply side (in addition to the "conventional" fiscal and balance-of-payments effects of aid).

Partly as a result, most existing exercises for determining requirements for meeting the MDGs, carried out in the context of PRSPs, have taken the form of a costing exercise of programs to be implemented during the PRSP implementation period. This "micro" approach to achieving the MDGs has paid insufficient attention to several key aggregate linkages between foreign aid, medium-term expenditure frameworks, growth, and the MDGs. Recent evidence suggests that such linkages may take the form of large positive externalities (for

\footnotetext{
${ }^{2}$ Two papers by Rajan and Subramanian (2005a, 2005b) appear to cast doubt on the view that aid may stimulate growth in low-income countries, essentially because of an adverse Dutch disease effect. Unfortunately, these studies suffer from several methodological and conceptual flaws. For instance, the authors fail to distinguish, in their empirical estimation, between fixed and floating exchange rate regimes. Under a flexible exchange rate regime, an aidinduced nominal appreciation will put downward pressure on the price of imported inputs (a key feature of the production structure in developing countries) and thus domestic inflation, thereby mitigating the inflationary effect of aid through the demand side. In addition, to the extent that aid leads to better infrastructure, it will improve competitiveness in the longer run (by reducing production costs), even if the real exchange rate appreciates in the short run. Because the time profile of these effects may vary significantly across countries, panel data regressions may provide misleading results on the dynamic effects of aid on the real exchange rate.
} 
instance, between public investment in health and educational attainment, or between capital outlays in infrastructure and literacy), which can be accounted for only in a macroeconomic framework. ${ }^{3}$ Ignoring these linkages implies that "micro" based approaches to MDG costing can be highly inaccurate and lead to over-estimation of foreign assistance needs.

This paper builds on the operational macroeconomic model developed by Agénor, Bayraktar and El Aynaoui (2005), and extended by Pinto Moreira and Bayraktar (2005), to develop a macroeconomic approach to monitoring achievement of the MDGs in Sub-Saharan Africa. The model accounts explicitly for the links between aid, public investment, and the supply side and provides some essential ingredients for understanding key trade-offs in the design of poverty reduction strategies. ${ }^{4}$ Specifically, we embed the model into a broader framework that incorporates cross-country regressions for Sub-Saharan African countries. This approach allows us to link directly policy and endogenous variables (such as public spending on health or income per capita) to the MDGs. Although we cannot account for all the MDGs in this setup (such as maternal mortality, or the plight of the poor living in city slums), we do explain the behavior of several important indicators-including the poverty rate, malnutrition, the infant mortality rate, percentage of population with access to safe drinking water, the literacy rate, and life expectancy at birth.

The remainder of the paper is organized as follows. Section II describes the methodology. Section III presents the baseline scenario for the country that we use to illustrate the functioning of our framework, Niger. Section IV discusses the effects of two policy experiments on the MDGs, an increase in foreign aid

\footnotetext{
${ }^{3}$ In a comprehensive review of the PRS approach, the German Development Cooperation (2005) identified the need to enhance linkages and consistency between the PRS, the mediumterm expenditure framework, and government budgets as one of the key priorities for enhancing the effectiveness of the approach. A similar emphasis was placed by the World Bank (2005) in its five-point agenda for accelerating progress toward the MDGs.

${ }^{4}$ The emphasis on public investment and the supply side in these models dwells on the more advanced class of IMMPA models, described in the collection of studies edited by Agénor, Izquierdo, and Jensen (2005).
} 
(namely, grants) and debt relief, under the assumption that public investment is fully efficient, in the sense that it translates one to one into a higher stock of public capital. Section $V$ examines the same policy experiments in the alternative case where public investment is only half as inefficient. Section VI provides some final remarks.

\section{Methodology}

At the heart of our framework is the macroeconomic model developed by Agénor, Bayraktar, and El Aynaoui (2005) and extended by Pinto Moreira and Bayraktar (2005). The model captures the links between foreign aid, the level and composition of public investment, the supply-side effects of public capital, growth, and poverty, in the context of a "typical" low-income country. It focuses on the fiscal and supply-side effects of aid, as well as the stock and flow effects of public investment---which is disaggregated into education, infrastructure (roads, electricity, telecommunications, and so on), and health---while accounting at the same time for potential congestion effects associated with the use of public services. It is designed to examine how debt relief, as well as increased aid and aid-funded levels of public investment, possibly coupled with changes in the allocation of public expenditure, can stimulate growth and lead to sustained poverty reduction.

Because it contains only one category of households, the model is silent on distributional issues. However, this is very much by design; the fundamental premise of our approach is that the ability to engage in substantial income or asset redistribution in Sub-Saharan Africa is limited for a variety of reasons 
(including the low level of income to begin with), and that the key to achieving the MDGs is a sustained increase in growth rates. ${ }^{5}$

The first part of this section describes the macro model and how it is related to poverty. The second part explains how macroeconomic variables (namely, income and consumption per capita), as well as poverty, are linked with the other MDG indicators.

\section{The Macro Model}

We begin by describing the production side, which is summarized in Figure 1. The economy produces one composite good, which is imperfectly substitutable to an imported good. Domestic production requires effective labor, private capital, and public capital in infrastructure and health. The stock of private capital is calculated by applying the standard perpetual inventory method. In the case of public investment, however, we account for the possibility that a fraction of the resources invested in investment projects may not have a positive impact on the public capital stock - a point emphasized by Prichett (1996) in the context of developing countries in general. Specifically, we follow the linear specification proposed by Arestoff and Hurlin (2005) and relate the stock of public capital in sector $h$ at period $t$, denoted $K^{h}(t)$, to the flow of investment in $h$, denoted $I G^{h}$, through the modified formula

$$
K^{h}(t)=\left(1-\delta^{h}\right) K^{h}(t-1)+\alpha I G^{h}(t-1)
$$

where $\delta^{h} \in(0,1)$ denotes the rate of depreciation of capital $h$ and $\alpha \in(0,1)$ is the efficiency parameter. The case of "full efficiency" corresponds therefore to $\alpha=1$. In the experiments reported below, we will also consider the case $\alpha<1$.

\footnotetext{
${ }^{5}$ Moreover, many observers have failed to note that redistribution may actually hurt the poor-by reducing savings and investment rates, or the ability to pledge collateral for borrowing against future income, for instance. See Agénor (2005c) for a more detailed discussion.
} 
While public capital in infrastructure improves the productivity of the private factors used to generate output, public capital in health improves the quality of labor employed in production. Effective labor is a composite input, which is produced by the actual stock of educated labor and public capital in health. In order to take into account congestion effects in the provision of health services, the stock of public capital in health is scaled by the size of the population. To account for congestion effects in domestic production, lagged output is used as an indicator of the intensity of use of public services in infrastructure. Domestic output is allocated between exports and domestic sales.

Population and "raw" labor grow at the same constant exogenous rate. The transformation of raw labor into educated labor takes place through the education system, which provides schooling services free of charge. A key input in this process is a composite public education input, which is a function of the number of teachers and the stock of public capital in education. But production of educated labor requires not only teachers and public capital in education but also access to infrastructure capital. This is a crucial feature of the model. As documented by Brenneman and Kerf (2002), many recent microeconomic studies have found a positive impact of infrastructure services on educational attainment, possibly through an indirect improvement in health indicators. A better transportation system and a safer road network (particularly in rural areas) help to raise school attendance. Greater access to safe water and sanitation enhance the health of individuals, increasing their ability to learn. Electricity allows more time to study and more opportunities to use electronic equipment that may improve the learning process. As far as we know, our model is the first to account for these effects in a quantitative macroeconomic framework. ${ }^{6}$ This adds an important channel of transmission of public investment to growth, through human capital accumulation.

\footnotetext{
${ }^{6}$ See Agénor $(2005 c, 2005 d)$ for a formal analysis of the implications of this specification in endogenous growth models. As discussed by Agénor (2005f), infrastructure may also have a significant impact on the production of health services.
} 
Figure 1

Public Capital and Production

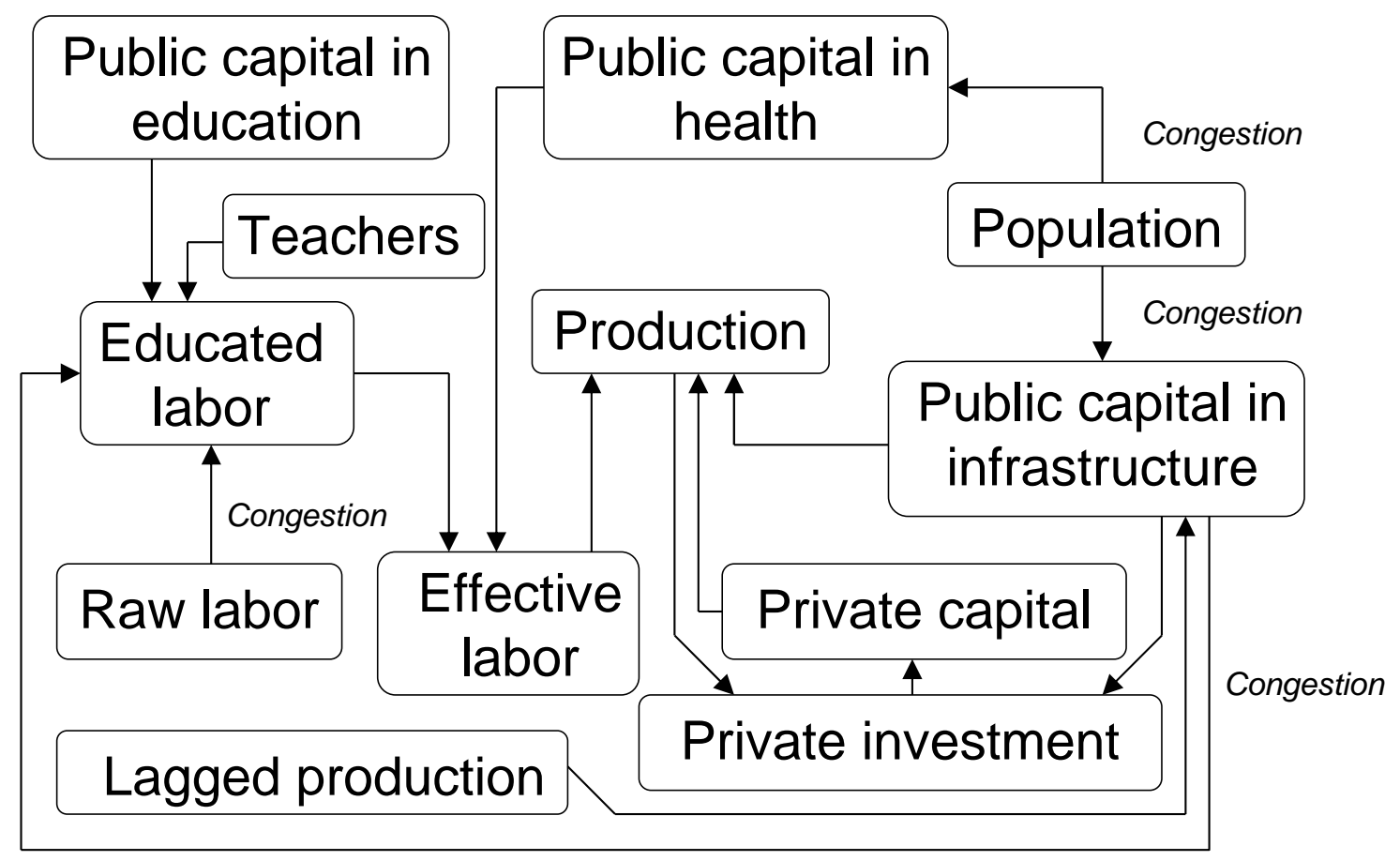

A congestion effect is introduced in the stock of public capital in education through raw labor, which captures pressure on the education system. Educated labor is employed either in the production of goods, or as government employees.

Income from production is entirely allocated to a representative household, who holds the totality of domestic public debt and receives interest payments on it. It also receives government wages and salaries, unrequited transfers from abroad, and pays interest on its foreign debt. Disposable income is obtained by subtracting direct taxes from total income. Total private consumption is a constant fraction of disposable income-an assumption that reflects the large body of evidence for low-income countries suggesting either tight liquidity constraints or short planning horizons (see Agénor (2004, Chapter 2)). 
Private investment is a function of the rate of growth in domestic output, private foreign capital inflows, and the stock of public capital in infrastructure. The latter variable captures the existence of a "complementarity" effect-by increasing the productivity of private inputs, or by reducing adjustment costs, a higher stock of public capital in infrastructure raises the rate of return on capital and leads to an increase in private investment. ${ }^{7}$

Total demand for goods sold on the domestic market is the sum of private and public spending on final consumption and investment. Goods bought and sold on the domestic market are the combination of imported goods and domestically-produced goods. The domestic good is imperfectly substitutable with the foreign good, and its relative price is endogenous. As a result, the model allows us to analyze potential Dutch disease effects that may be associated with large aid flows in a fixed-exchange rate economy such as Niger through increases in domestic prices.

Aid, defined only as grants, is linked to the government budget through various channels (see Figures 2 and 3). The government collects taxes and spends on salaries, goods and services, interest payments, and accumulates public capital. Aid is accounted for "above the line"; it is therefore a potential substitute to domestic sources of revenue. The deficit is financed through domestic borrowing and foreign borrowing (concessional or not). Taxes are defined as the sum of direct, domestic indirect, and international (import) taxes. Total public investment is allocated (using fixed fractions) between health, education, and infrastructure. The effective direct tax rate is negatively related to the aid-to-GDP ratio, and positively to total government expenditure. Aid captures therefore an adverse effect of foreign assistance on fiscal effort. The effective indirect tax rate is also negatively related to aid. Current non-interest expenditure on goods and services is assumed to be constant as a proportion of GDP.

\footnotetext{
${ }^{7}$ See Agénor, Nabli and Yousef (2005) for a detailed discussion of these effects and a review of the empirical evidence for developing countries.
} 
Figure 2

Impact of Foreign Aid

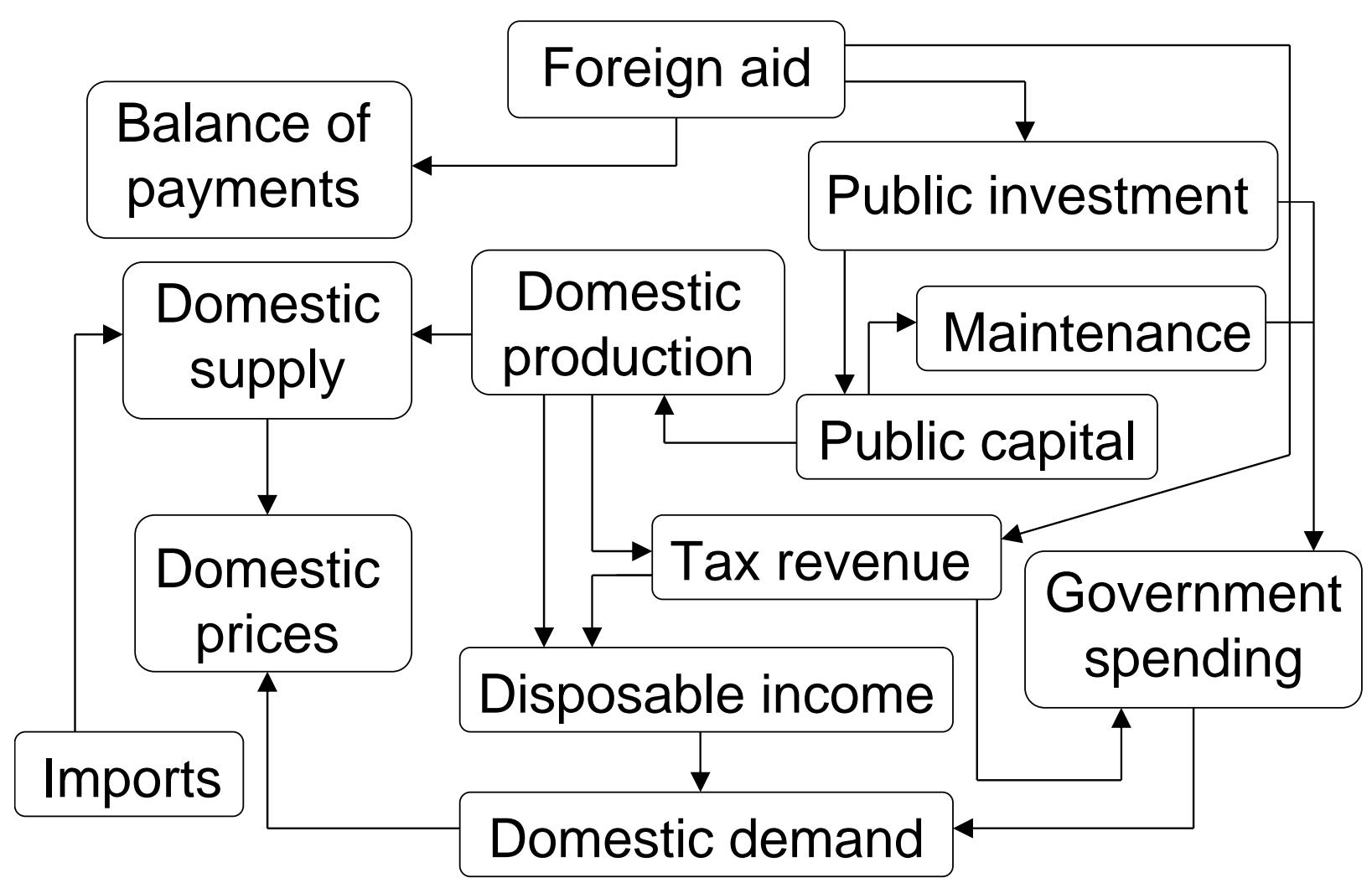

Total public investment is positively related to both tax revenue (a measure of the capacity to raise domestic resources) and foreign aid. To account explicitly for the implications of a higher capital on stock on recurrent spending (and thus financing needs), maintenance expenditure is related to depreciation of all stocks of public capital. ${ }^{8}$ Accounting for "required" maintenance outlays as we do is important; inadequate funding for maintenance has been a chronic problem

${ }^{8}$ We do not account here for "feedback" effects of maintenance expenditure, most notably on the rate of depreciation of the public capital stock, as well as possibly on the durability of private capital (all depreciation rates are assumed constant). The key idea in the latter case is that maintaining the quality of roads, for instance, enhances the durability of trucks and other means of transportation used by the private sector to move labor and goods. Similarly, with a more reliable power grid, electrical equipment may last longer. See Agénor (2005e) for a formal analysis of the implications of endogenizing depreciation rates. 
in many developing countries, resulting in rapid decay of public capital, such as roads and power grids.

Figure 3

Government Budget

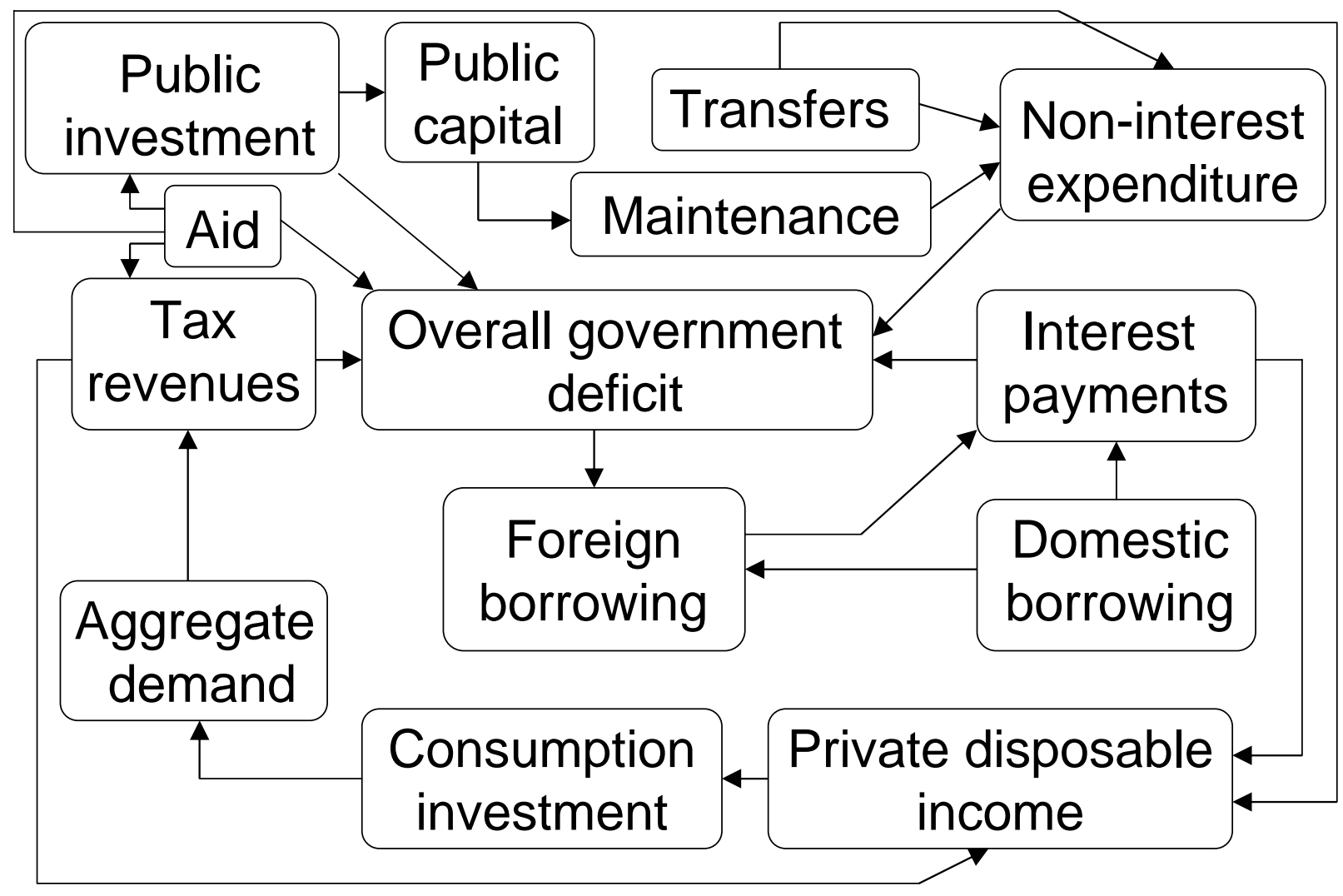

The financing constraint of the government implies that the budget balance is financed through domestic and foreign borrowing. From the household budget constraint, private savings is determined by a constant saving rate and disposable income.

The balance of payments is obtained by subtracting foreign interest payments and changes in net foreign assets of the central bank from the sum of net exports, private and public capital flows, aid, and unrequited transfers from 
abroad. The stocks of private and public foreign debt are obtained by adding the current period capital flow to the debt level of the previous period.

The price of the composite good is a function of the price of the domestically-produced good and the domestic-currency price of imports (defined as the product of the nominal exchange rate and the world price of imports, inclusive of tariffs). Market equilibrium requires equality between total supply of goods on the domestic market and aggregate demand for these goods, which in turn determines the equilibrium (composite) price. The price of the domestic good on the domestic market, however, is assumed to adjust only gradually to its equilibrium value. Finally, the domestic-currency price of exports is equal to the exchange rate times the world price of exports.

\section{Link with the MDGs}

Our approach to monitoring the MDGs is summarized in Figure 4. Six of the MDG indicators are integrated: the poverty rate, the literacy rate, infant mortality, malnutrition, life expectancy, and access to safe water. A key feature of our approach is that the MDG indicators also interact with each other, in a way that is made precise through our cross-country regressions.

The poverty rate is linked directly to the macroeconomic model. Specifically, the model is linked to poverty through either partial growth elasticities relating a poverty indicator to consumption, or a household survey. The first method consists of relating the poverty rate (as measured by the headcount index) to the growth rate of real private consumption per capita, as derived from the model. In the absence of more precise country estimates (as in the case of Niger discussed later), we use three partial elasticity values: a "neutral" or central value of -1 , a "low" value of -0.5 , and a "high" value of -1.5 . These values are consistent with the range of evidence on the "growth elasticity" of poverty for Sub-Saharan Africa and can, of course, be changed. For instance, 
the value -0.5 is close to the estimate obtained by Besley and Burgess (2003, Table 2) for Sub-Saharan Africa, and by Christiansen, Demery, and Paternostro (2003, Table 4) for Ethiopia and Zambia. In addition, we also use the "adjusted" elasticity formula proposed by Ravallion (2004, pp. 12-13). With a Gini coefficient equal to 50.5 for Niger, the formula gives an elasticity of -1.13 .

Figure 4

Monitoring the MDGs: A Macroeconomic Approach

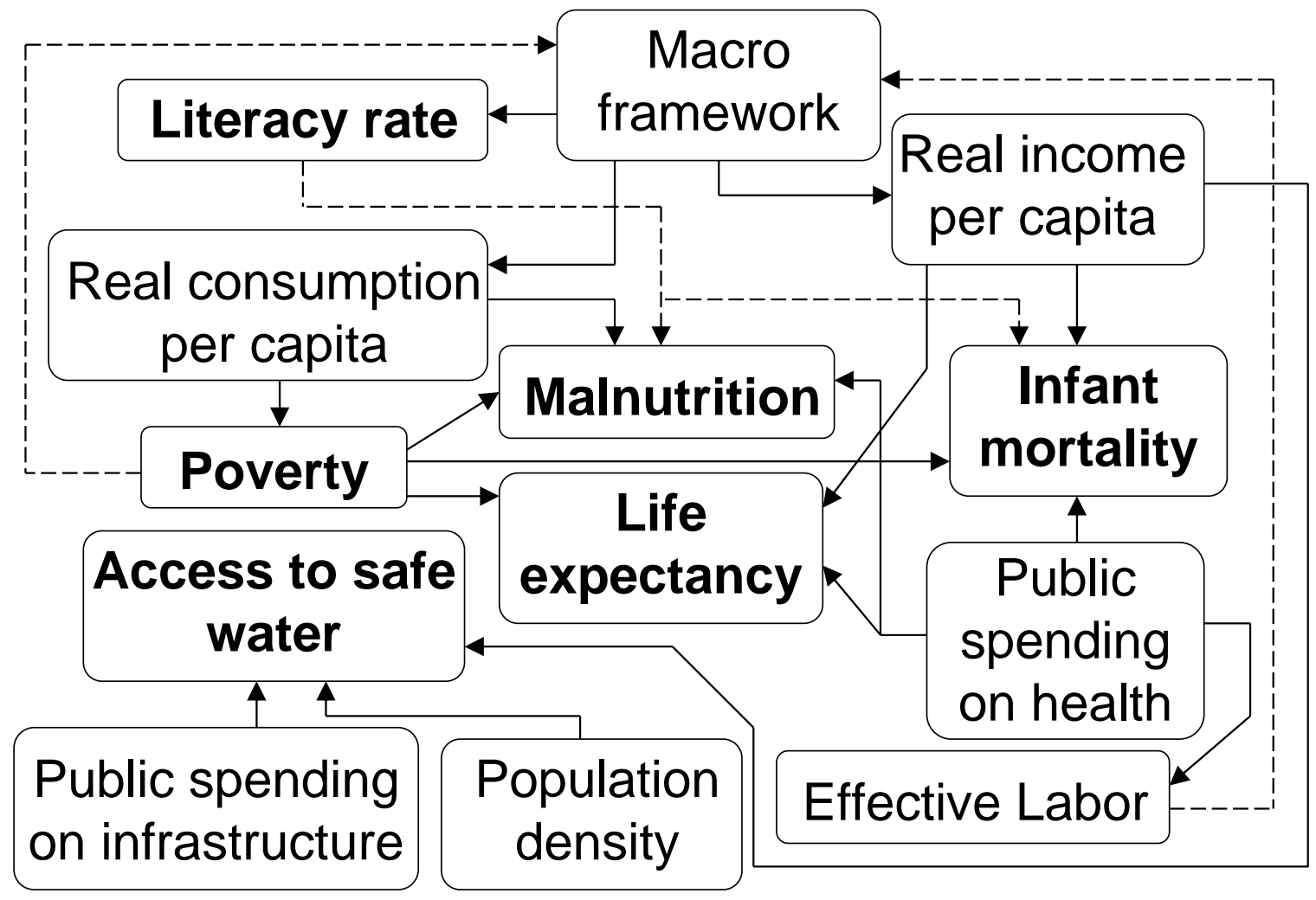

The second methodology, which involves linking the model to a household survey, involves several steps and is summarized in Figure 5. First, using a representative income and expenditure survey, the value of consumption spending for each household is extracted, and given the poverty line, the initial poverty rate is calculated. Second, following a policy or exogenous shock, the growth rate in private consumption per capita is generated in the macroeconomic model, up to the end of the simulation horizon (say, $N$ periods). Third, this growth 
rate is applied to the consumption expenditure data for each household in the survey. This gives new consumption levels for each unit, for periods $1, \ldots N$. Fourth, the poverty line is updated by using the growth rate of the consumer price index generated by the macroeconomic model. Finally, using the new data on nominal consumption per household and the poverty line, "post-shock" poverty indicators are calculated and compared with initial indicators to assess the poverty effect of the shock.

Figure 5

Link with a Household Survey

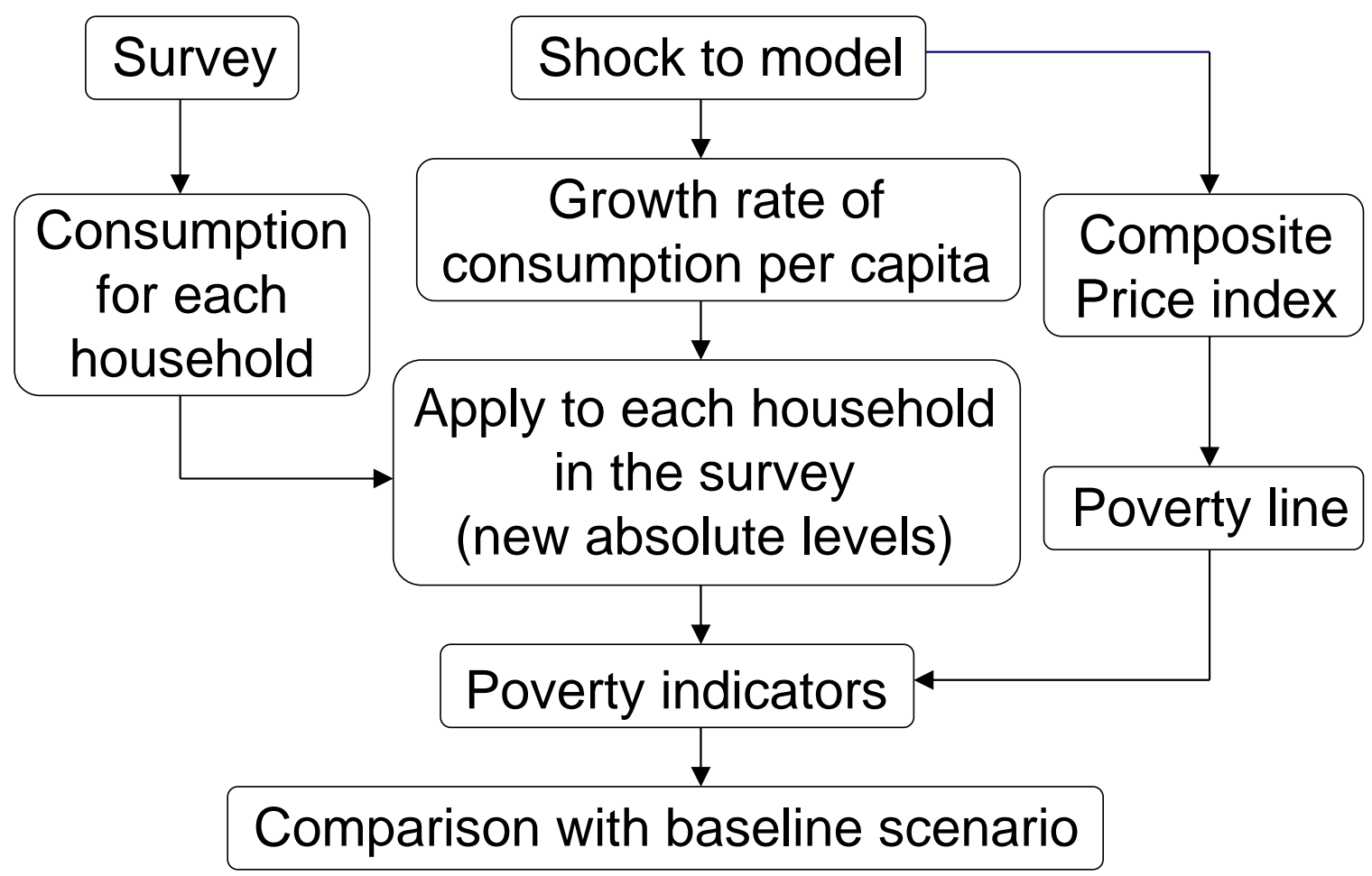

The literacy rate, which is defined as the ratio of educated labor to total population, is also a direct output of the model. It is only an approximation to the conventional definition, which related to the proportion of the population aged 15 years and over which is literate. 
All other MDG indicators (malnutrition, infant mortality, life expectancy, and access to safe water) are linked to the model through cross-country regressions, which allow us to alleviate the lack of observations at the level of individual countries. We use a cross-section estimation technique, in order to focus on long-run relationships. Given that all the MDG indicators considered here tend to change slowly over time, this appears to be a more sensible strategy than using, say, dynamic panel techniques. These regressions are discussed in some detail in the Appendix.

Malnutrition prevalence is linked to the model through real consumption per capita, the poverty rate, and public spending on health. ${ }^{9}$ While increasing consumption per capita and public spending on health reduces the incidence of malnutrition, an increase in the poverty rate raises it. Infant mortality is inversely related to poverty, and positively related to real income per capita and public spending on health. ${ }^{10}$ Thus, declining poverty may not be sufficient to decrease infant mortality if public investment in health is not increasing sufficiently. ${ }^{11}$

Public spending on health also has a positive effect on life expectancy, which can be viewed as a "summary" indicator of the goal of combating diseases. Besides public investment in health, lower poverty rates and higher real income per capita also tend to increase life expectancy. Our evidence on the impact of

\footnotetext{
${ }^{9}$ See Broca and Stamoulis (2003) for a more general discussion of the micro- and macrodeterminants of malnutrition. Our results are consistent with those of Smith and Haddad (1999), who used data from 63 countries in five regions (covering 88 percent of the developing world's population over the period from 1970-95) to analyze the determinants of child malnutrition, as measured by the percentage of underweight children under five. They found that growth in per capita national income (which is closely correlated with consumption per capita) contributed to half the reduction in child malnutrition over this period.

${ }^{10}$ In general, one would expect infant mortality to be also determined by malnutrition prevalence. We did not, however, introduce this link because we could not find empirical support for it in our cross-country regressions.

${ }^{11}$ Another important effect of increasing public spending on health (as noted earlier) is that it raises effective labor, which improves efficiency, thus economic growth. Note that, due to lack of data, our regressions use "flows" rather than "stocks" of public expenditure.
} 
income is consistent with the results obtained by Baliamoune and Lutz (2004) in a larger sample of countries. ${ }^{12}$

The share of population with access to safe water is taken to be a function of population density, real income per capita, and public spending on infrastructure. The effect of population density on access to safe water is positive because the cost of building infrastructure capital tends to drop with higher density. Similarly, increasing real income per capita raises the share of population with access to safe water, possibly as a result of "demand" pressures. And naturally enough, public investment in infrastructure raises access to safe water-both directly and possibly indirectly as well, through its impact (captured in the model) on real income per capita.

To provide a synthetic view on progress toward achieving the MDGs, we also calculate a composite index by taking an unweighted geometric average of all the individual indicators defined earlier-the literacy rate, life expectancy, access to safe water, as well as the inverse of the poverty rate (as obtained in the "neutral elasticity" case), malnutrition prevalence, and infant mortality. Thus, a rise in the index indicates overall progress toward achieving the MDGs. Our composite index is thus more general than the human development index published in recent years by the United Nations Development Program in its Human Development Report, which is an unweighted arithmetic average of the (normalized) values of real GDP per capita, life expectancy, and the educational attainment rate. ${ }^{13}$

\footnotetext{
${ }^{12}$ One would also expect life expectancy to be affected by malnutrition prevalence, but our empirical findings did not support this link.

${ }^{13}$ See Chakravarty (2003) for a discussion of the theoretical underpinnings of this index.
} 


\section{Baseline Projections}

To illustrate the functioning of the framework described in the previous section, we apply it to Niger. With 63 percent of the population living below the poverty line, and 34 percent considered as extremely poor, Niger is the second poorest country on earth. ${ }^{14}$ Despite recent improvements, social indicators remain abysmal, and among the weakest in the world (see Table 1). Child malnutrition is high and estimated at 40 percent, compared with an average of 26 percent in Sub-Saharan Africa. The infant mortality rate (deaths per 1,000 births) is currently 155, whereas it averages 96 for the continent as a whole. Less than 60 percent of the population has access to potable water and only 5 percent of the rural population has access to sanitation facilities. Life expectancy at birth is about 46 years, compared with an average of 48 years in Sub-Saharan Africa. At 17 percent, the literacy rate is among the lowest in the world and far below the average for the region, estimated at 60 percent.

We first established a baseline projection using the macro framework described earlier, based on assumptions that reflect recent trends regarding aid, prices of exports and imports, capital flows, and so on. ${ }^{15}$ In particular, the aid-toGDP ratio is assumed to remain constant at 10.7 percent until 2015, and foreigncurrency prices of exports and imports are assumed to grow at the same rate, so that we exclude net gains in the terms of trade. Domestic borrowing is kept at 1 percent of GDP (the value observed in the base period) and tax rates that are exogenous are also kept constant.

\footnotetext{
${ }^{14}$ The United Nations Development Program, using its Human Development Index, ranked Niger 176 out of 177 countries in 2004.

${ }^{15}$ The complete set of simulation results, and details about the calibration process, are available upon request.
} 
Table 1

Niger: MDG Indicators, 1990 and 2002

\begin{tabular}{|c|c|c|c|c|}
\hline & \multicolumn{2}{|c|}{ Niger } & \multicolumn{2}{|c|}{ Sub-Saharan Africa } \\
\hline & 1990 & 2002 & 1990 & 2002 \\
\hline $\begin{array}{l}\text { Poverty rate } \\
\text { (\% of the population living below } \$ 2 \text { per day) }\end{array}$ & $\begin{array}{c}63 \\
\text { (in 1993) }\end{array}$ & $\begin{array}{r}63.0 \\
(\text { in } 2003)\end{array}$ & 44.7 & 55.5 \\
\hline $\begin{array}{l}\text { Literacy rate } \\
\text { (\% of educated labor in total population) }\end{array}$ & 11.4 & 17.1 & 48.5 & 60.3 \\
\hline $\begin{array}{l}\text { Infant mortality } \\
\text { (Infant mortality rate per } 1000 \text { live births) }\end{array}$ & 191 & 155.0 & 104.2 & 96.3 \\
\hline $\begin{array}{l}\text { Malnutrition } \\
\text { (Malnutrition prevalence, weight for age) }\end{array}$ & $\begin{array}{r}42.6 \\
\text { (in 1992) }\end{array}$ & $\begin{array}{r}40.1 \\
(\text { in } 2000)\end{array}$ & 27.8 & 26.3 \\
\hline $\begin{array}{l}\text { Life expectancy } \\
\text { (Life expectancy at birth, years ) }\end{array}$ & 42.1 & 46.2 & 50.6 & 48.2 \\
\hline $\begin{array}{l}\text { Access to safe water } \\
\text { (Percentage of population with access to safe water) }\end{array}$ & 53.0 & $\begin{array}{r}59.0 \\
\text { (in } 2000)\end{array}$ & 59.1 & 60.5 \\
\hline
\end{tabular}

Note: Sub-Saharan countries exclude South Africa and oil-exporting countries.

Most importantly, we assume for the moment that public investment is "fully efficient", in the sense that it translates CFA franc for CFA franc into an increase in the public capital stock. This corresponds to the case where $\alpha=1$ in equation (1). Thus, we assume that in the coming years Niger will continue to implement institutional reforms that will help to improve governance, strengthen management of public resources, reduce corruption, and eliminate much of the waste that all too often characterized capital outlays in the past.

Baseline projections are shown in Table 2 for the period 2005-15. The results show that poverty drops throughout the simulation period. As shown in Table 2, the headcount index decreases in the "best" case (a consumption growth elasticity of -1.5 ) by 25.1 percentage points, down to 37.9 percent in 
2015, from an estimated 63 percent in 2003. However, in the Besley-Burgess case (a consumption growth elasticity of -0.5 ), the poverty rate drops by 10.9 percentage points only, over the same period. Thus if current trends were to be maintained, the MDG of halving poverty would not be achieved by 2015 . Indeed, in these circumstances, relative to 2003 , it would take 15 years (or a target date of 2018) in the high elasticity case, or 39 years (or a target date of 2042) in the Besley-Burgess case, for Niger to reduce its poverty rate in half.

Regarding the other MDG indicators reported in Table 2, the literacy rate (defined as the ratio of educated labor to total population) increases from 17.1 percent in 2003 to 27.6 in 2015, as a result of an increase in public investment in education and infrastructure combined with an increasing number of teachers. Whereas infant mortality drops from 155 in 2002 to 119 in 2015, malnutrition prevalence drops only slightly from 40.1 percent in 2000 to 36.8 percent in 2015. These improvements are a result of a combination of factors--reduction in poverty, increased public investment in health, and higher GDP and private consumption per capita. ${ }^{16}$ For similar reasons, life expectancy also increases, from 46.2 in 2002 to 49.1 in 2015.

The last individual indicator, the percentage of population with access to safe water, rises from 59 percent in 2000 to 61.4 percent in 2015 as a result of increasing public investment in infrastructure, and higher GDP per capita and population density, all of which are estimated to have a positive effect on access to safe water. In sum, the MDG indicators improve quite sensibly in Niger; the composite MDG index (which is defined as a geometric average with base 2005 $=100$ for convenience) shows a significant overall improvement, increasing by 23 percentage points. But again, despite these improvements, Niger will not be able to achieve the MDG targets by 2015 based on recent trends. In particular, halving poverty and malnutrition by 2015 will require more effort.

\footnotetext{
${ }^{16}$ The elasticity used to link poverty and the MDGs corresponds to the "neutral" case of unity. Adjusting this parameter is of course straightforward.
} 


\section{Policy Experiments}

Given that our baseline scenario suggests that achieving the MDGs is unfeasible based on current trends, we consider two experiments: the first is a permanent increase in the ratio of foreign aid to GDP by 5 percentage points, whereas the second is a complete write-off of the outstanding stock of foreign debt. Both shocks are assumed to occur in 2006. Again, given the illustrative nature of the exercise, we provide only a concise description of the transmission channels. ${ }^{17}$ We also focus our discussion on a comparison between 2005 and 2015, although a comparison between 1990 and 2015 would be more in line with a strict assessment of progress toward achieving the MDGs.

\section{Increase in Foreign Aid}

The immediate macroeconomic effect of an increase in aid is an increase in aggregate demand. This, in turn, puts upward pressure on domestic prices. Given that the nominal exchange rate is fixed, the real exchange rate appreciates, which tends to dampen exports (and to raise sales of the domestically-produced good on the domestic market) and increase imports. The magnitude of these effects is, however, dampened by the fact that prices adjust only partially in the short run, whereas the reallocation of output, as well as the composition of demand, changes only gradually. Put differently, there is indeed a "Dutch disease" effect, but its magnitude is not large.

Moreover, this effect is mitigated over time. The increase in foreign aid leads to an increase in public investment. Because the shares of each component of public investment are fixed at baseline levels (and are thus constant throughout the simulation period), all components of public investment increase. This results in an increase in the stock of capital in education and

${ }^{17}$ More details on these experiments are provided in Agénor, Bayraktar and El Aynaoui (2005) and Pinto Moreira and Bayraktar (2005). 
infrastructure, and the "public education input," which therefore leads to the production of a higher number of educated workers. This increase, combined with the rise in the stock of public capital in health, leads to greater availability of "effective" labor. This supply-side effect develops gradually, raising private spending and consumption, and dampening the initial inflationary effect of the increase in aid. This effect is, in a sense, self-reinforcing: because tax revenues increase also over time (despite an adverse "moral hazard" effect of aid on collection effort), there is an additional positive effect on public investment. Indeed, although the increase in aid tends to reduce incentives to collect taxes (thereby leading to lower "effective" tax rates on both income an domestic sales), the tax base tends to increase, as a result of higher domestic income and the rise in imports induced by the real appreciation. The net effect is that overall tax revenues tend to increase, thereby raising capital outlays. An important implication of this result is that an aid-induced reduction in (indirect) taxation may be beneficial to the poor in the short term - to the extent that it mitigates upward pressure on prices of goods sold domestically—but in the longer term, it may hurt them, by reducing the capacity to finance public investment and mitigating supply-side effects.

The effects of this experiment on the MDGs are shown in Table 3. The headcount index based on a partial elasticity of -1.5 falls by 38 percentage points, from an estimated 66.9 percent in 2005 to 28.9 by 2015 . However, with an elasticity of -0.5 , the drop is 15.3 percentage points, and poverty is estimated at 49 percent in 2015 . Thus in the high elasticity case of -1.5 , and full efficiency of public investment, the simulation suggests that a 5 percentage-point increase in aid leads to a reduction in poverty by half between 2005 and 2015. But the simulation also suggests that foreign aid may need to be increased by more than 10 percentage points of GDP in the Besley-Burgess case of a consumption growth elasticity of -0.5 even if public capital outlays are fully efficient. Given the baseline assumptions, this would bring the aid-to-GDP ratio to almost 22 percent. 
Whether, at that level, absorption constraints may "kick in" and become binding is an open issue.

Because, as noted earlier, the increase in public capital in education and infrastructure leads to the production of a higher number of educated workers, the literacy rate increases by 3.7 percentage points, from an estimated 19.2 percent in 2005 to 31.3 percent by 2015 . The incidence of child malnutrition also falls, both directly and indirectly. The increase in Government resources associated with a rise in aid increases public investment and capital in health, whereas the increase in real private consumption per capita tends to reduce poverty; both effects tend to reduce malnutrition. Given the estimated parameters, the net effect is a drop in this indicator, by 8.9 percentage points by 2015 (from 41.1 percent to 32.2 percent).

The reduction in poverty and the rise in public capital in health are associated with a reduction in infant mortality, which falls from an estimated 156 per 1000 live births in 2005 to 102 in 2015 . Thus, the simulation results suggest that reducing the under-five mortality rate by two-thirds could be achieved in Niger through the increase in aid considered here. Life expectancy also improves, from an estimated 46.4 years in 2005 to 51.7 years in 2015. Increasing real income per capita, as well as public capital in infrastructure, leads to an increase in access to safe water, from 57.5 percent in 2005 to 62.7 percent in 2015. Overall, by 2015 the composite MDG index improves by about 14.4 percentage points relative to the baseline scenario.

\section{Cancellation of External Debt}

Following recent decisions by G-8 countries, debt cancellation is at the forefront of the policy agenda for many LICs. For this experiment, we assume that the outstanding stock of Niger's external debt is cancelled in 2006, and that in the following years "new" borrowing occurs only at a very low effective interest 
rate, of 0.2 percent. ${ }^{18}$ We assume that the savings associated with lower interest payments (which represent about 0.52 percent of GDP in 2006) are reallocated entirely to public investment.

On impact, debt relief has no effect on the budget and aggregate demand. Over time, because public investment increases, public capital in infrastructure, education and health also increase, generating positive supply-side effects. As described above, these effects tend to strengthen over time. At the MDG horizon, however, gains are relatively limited, given the magnitude of the savings realized; by 2015, the growth rate in per capita output at factor cost is only about 0.2 percentage points higher than the baseline value.

Results of this experiment on the MDGs are shown in Table 4. The direction of the effects on all indicators is similar to those associated with an increase in aid-poverty falls, literacy and access to safe water improves, and malnutrition and infant mortality drop. But, given the magnitude of the shock, by 2015, the composite MDG indicator improves by less than 2 percentage points relative to the baseline scenario.

An interesting question is whether the impact of debt relief compares favorably with a permanent increase in aid of the exact same magnitude, of about 0.52 percentage of GDP, beginning also in 2006. The results (which are not reported here to save space) show that an increase in aid has a slightly larger impact; the composite MDG indicator improves by 1.7 at the horizon 2015 (compared to 1.6 for the debt relief experiment). The reason is that the increase in aid has a slightly bigger effect on aggregate demand, because (as noted earlier) it lowers incentives to collect taxes; the reduction in the effective direct tax rate leads to an increase in private disposable income and spending. In turn, the increase in spending puts upward pressure on prices. The real exchange

\footnotetext{
${ }^{18}$ An alternative "closure rule" for the budget would be to assume that the deficit is financed by additional grants. However, doing so in the present context would mix the effects of debt relief with those of additional aid, and blur differences in the transmission mechanism.
} 
rate therefore appreciates more, and imports increase by more, than in the debt relief case. As a result, tariff revenues increase by more. The overall effect on total revenues is positive-despite the fact that the moral hazard effects of aid lead to slightly lower revenues collected on domestic sales and private income. Because public investment depends also on domestic resources, higher tax revenues magnify the positive effect of the initial increase in foreign aid on public capital accumulation.

A key reason why the debt relief experiment does not deliver stronger results (despite the assumption that all interest savings are allocated to public investment) is not only due to the magnitude of the shock but also to the fact that the macro model on which the analysis is based does not account for the possibility of a reverse "debt overhang" effect. In the presence of a debt overhang problem, a reduction in foreign debt, by reducing the perceived risk of taxation or confiscation, would stimulate private investment (above and beyond the complementarity effect discussed earlier), thereby magnifying supply-side effects. But although there is evidence in favor of such an effect for low-income countries in general (as discussed by Agénor (2004, Chapter 2)), we did not find strong evidence in favor of it in the specific case of Niger. The policy implication, of course, is that debt relief must be accompanied by a large and sustained increase in aid if Niger is to reach the MDGs.

\section{Inefficient Public Investment}

The foregoing analysis assumed that public investment is fully efficient, in the sense that all capital outlays in education, infrastructure, and health serve to increase one to one the public capital stock. We now briefly consider the case where inefficiency persists, or that reforms aimed at improving governance and eliminate mismanagement of public resources are not sufficiently deep. Because we do not have specific estimates of the parameter $\alpha$ in equation (1) for Niger, 
we chose a value of 0.5 for all categories of public capital. This is consistent with Pritchett's (1996) estimate that half of all capital outlays are wasted in developing countries. It also corresponds to the mid-point of the range of values-between 0.4 and 0.6-estimated by Arestoff and Hurlin (2005).

The baseline scenario, as well as the results of the two experiments described in the previous section, are summarized in Tables 5 to 7 . The key implication is that, in the absence of appropriate reforms aimed at improving the management of capital outlays, progress toward all the MDG indicators will be hampered. In particular, in the baseline scenario, the composite indicator will improve by only 13.4 percentage points between 2005 and 2015 (compared to 23 in the full efficiency case); and even in the high elasticity case, the poverty rate will fall only from 66.9 in 2005 to 47.7 (instead of 37.9 ). To halve the poverty rate relative to 2003, it would take now 25 years (or a target date of 2028) in the high elasticity case, and 69 years (or a target date of 2072) in the BesleyBurgess case. A 5-percentage point increase in the aid-to-GDP ratio would lead to an improvement in the composite MDG indicator of 10.5 percentage points by 2015 relative to the baseline (instead of 15.1), whereas a debt write-off would lead to an improvement of 1.2 at the same horizon (compared to 1.6). To achieve the poverty MDG in 2015, the aid-to-GDP ratio would need therefore to increase to 26.6 percent in the Besley-Burgess case-exacerbating therefore the potential problems of absorption capacity that were discussed earlier.

To the extent that a coefficient of $\alpha=0.5$ is an adequate estimate for Niger in the coming years, the lesson from this alternative set of experiments is clearwithout adequate reforms to strengthen the management of public resources and eliminate waste, the benefits that an increase in foreign aid or a debt write-off can bring in terms of the MDGs can be significantly hampered. In that sense, our results accord well with the view adopted by some that governance (defined broadly to include the efficient management of public funds) must improve to make aid effective. 


\section{Conclusions}

The purpose of this paper was to present an integrated macroeconomic approach to monitoring progress toward achieving the Millennium Development Goals (MDGs) in Sub-Saharan Africa. At the heart of our approach is the macro model developed by Agénor, Bayraktar and El Aynaoui (2005) and extended by Pinto Moreira and Bayraktar (2005). A detailed presentation was provided in the first part of the paper. A key feature of the model is a production function that accounts explicitly for the effect of public capital (in health and infrastructure) on output and the marginal productivity of private production inputs. Public capital in education also plays a role in the production process, because "raw" labor must be turned into educated labor to become productive. The domestic (composite) good is imperfectly substitutable with the foreign good. By accounting for changes in relative prices, potential Dutch disease effects associated with aid flows can therefore be analyzed. In addition, the model captures explicitly the link between aid and public investment, and the possible adverse effects of large inflows of foreign aid on fiscal accounts (most notably the incentive to collect taxes and pressure on current spending). Finally, the impact of policy shocks on poverty is assessed either by linking the model to a household survey or by using partial elasticities relating consumption growth to poverty, using a range of available estimates for low-income countries.

By linking the model through cross-country regressions to indicators of malnutrition, infant mortality, life expectancy, and access to safe water, we provided a consistent framework for evaluating the impact of policy decisions on the MDGs. The functioning of our framework was illustrated by simulating the impact of a 5-percentage point increase in the share of foreign aid in GDP and debt cancellation in Niger for the period 2006-15. We conducted the two experiments under two alternative assumptions regarding the degree of efficiency of public investment: full efficiency, in which all investment outlays serve to increase the capital stock, and partial efficiency, where only half of every 
currency unit spent helps to raise the stock of public capital. Overall, our results showed that a debt write-off, while welcome for a low-income country like Niger, will be insufficient to allow the country to reach the MDGs; an increase in aid is essential in that regard. At the same time, however, the magnitude of the required increase, if the elasticity of poverty with respect to consumption growth is relatively low (as suggested by Besley and Burgess (2003)) and if public investment is relatively inefficient, may well be unfeasible due to absorption constraints. In such conditions, a gradual and sustained increase in foreign assistance may be preferable.

The analysis presented in this paper can be extended in various directions. It would be important, for instance, to account for the impact of health on educational attainment-and thus indirectly on growth, poverty, and other social indicators. A growing body of evidence (aptly documented by Bundy and others (2005)) has shown that health is an important factor in determining both the quantity and quality of human capital. Healthier children tend to do better in school, just like healthier workers perform their tasks better (as captured in our macro model). Accounting for these effects in a macroeconomic context may be quite challenging, due to the difficulty of estimating reliable parameters with limited data, but would be well worth the effort.

Another issue worth investigating is the possibility of "reverse linkages" between the MDGs and the macro model. At the moment, the only feedback effect is from the literacy rate to the supply side. But several other channels could be envisioned. For instance, as indicated by a dotted line in Figure 4, a high poverty rate could lower the propensity to save and invest, along the lines of the "vicious circle" described by Nurkse (1953). Alternatively, malnutrition could be modeled as having an adverse effect on labor productivity - a well-documented fact in micro studies (see Broca and Stamoulis (2003)). Estimating these relationships could be difficult at the country level, but using cross-section 
regressions (as was done here) could help to alleviate problems of degrees of freedom.

Our contention, however, is that even in its present form the approach proposed in this paper does provide policymakers in Sub-Saharan Africa with a unique operational framework to quantify the impact of some key policy choices on their ability to achieve the MDGs. Many observers agree that a fundamental policy issue for many low-income countries is the allocation of public investment-an issue that lies at the heart of our approach.

From a practical standpoint, our approach also has considerable appeal. We know full well how to make more complicated models, with multiple sectors and households, while at the same time capturing also the dynamics of public investment, segmented labor markets, credit market imperfections, and many other important features that matter for growth and employment. A prominent class of models in that category is IMMPA, which has been applied to a number of middle-income countries, including Bolivia, Brazil, Colombia, Morocco, Tunisia, and Turkey (see Agénor, Izquierdo, and Jensen (2005)). However, in a lowincome environment where data are limited and human capital scarce, building complex models may simply not be feasible. The macro model that lies at the core of our approach was built in about 6 to 8 months for two countries (Ethiopia and Niger) for which data are comparable in quality and availability to other LICs in Sub-Saharan Africa. Using the cross-country regressions presented in this paper, our approach should be therefore relatively easy to replicate for a number of other countries in the region. Doing so would enable these countries to strengthen the analytical basis for designing their PRSP and improve the quality of the policy debate-particularly regarding the likely effects of increased aid and the level of assistance needed to meet the MDGs.

Our approach also brings to the fore the limitations of the current concept of "Poverty Reduction" Strategy Papers. The implicit focus on poverty in this 
approach is too narrow, and does not account for the fact that other social indicators may be equally important in assessing the implications of a particular development strategy. The fact that such indicators may be correlated with poverty does not imply that reducing the incidence of poverty will necessarily lead to improvements in those dimensions as well; targeted policy measures may be essential. A more encompassing term than PRSP, emphasizing the different dimensions of human development, would redress any sense of imbalance in policy objectives and strategies to attain them. Our proposed term is Strategy Papers for Human Development, or SPAHD. This is more, in our view, than simply a matter of semantics. It would help to provide a constant reminder to all parties involved that although it is increasingly clear that many low-income countries are unlikely to attain the MDGs by the target date of 2015 , the objectives set forth in the Millennium Declaration should remain a focal point of the development agenda for years to come. 


\section{References}

Agénor, Pierre-Richard, The Economics of Adjustment and Growth, second ed, Harvard University Press (Cambridge, Mass.: 2004).

- "Infrastructure, Public Education and Growth with Congestion Costs," Working Paper No. 47, Centre for Growth and Business Cycle Research, University of Manchester (January 2005a).

—, "Fiscal Policy and Growth with Public Infrastructure," unpublished, University of Manchester (May 2005b).

- "The Macroeconomics of Poverty Reduction," Manchester School of Social and Economic Studies, 73 (July 2005c), 369-434.

_-,"Schooling and Public Capital in a Model of Endogenous Growth," unpublished, University of Manchester (July 2005d).

- ,"Infrastructure Investment and Maintenance Expenditure: Optimal Allocation Rules in a Growing Economy," unpublished, University of Manchester (July 2005e).

- "Health and Infrastructure in Models of Endogenous Growth," unpublished, University of Manchester (September 2005f).

- "Quantifying the Macroeconomic Effects of Public Infrastructure: Methods and Applications," work in progress, University of Manchester (September 2005g).

Agénor, Pierre-Richard, Nihal Bayraktar, and Karim El Aynaoui, "Roads out of Poverty? Assessing the Links between Aid, Public Investment, Growth, and Poverty Reduction," revised, World Bank (September 2005).

Agénor, Pierre-Richard, Derek Chen, and Michael Grimm, "Linking Representative Household Models with Household Surveys," in Pierre-Richard Agénor, Alejandro Izquierdo, and Henning Tarp Jensen, forthcoming, Blackwell Publishing (Oxford: 2005).

Agénor, Pierre-Richard, Alejandro Izquierdo, and Henning Tarp Jensen, eds., Adjustment Policies, Poverty and Unemployment: The IMMPA Framework, forthcoming, Blackwell Publishing (Oxford: 2005).

Agénor, Pierre-Richard, Mustapha K. Nabli, and Tarik M. Yousef, "Public Infrastructure and Private Investment in the Middle East and North Africa," Policy Research Working Paper No. 3661, World Bank (July 2005). 
Arestoff, Florence, and Christophe Hurlin, "The Productivity of Public Capital in Developing Countries," unpublished, University of Orléans (March 2005).

Baliamoune, Mina, and Stefan Lutz, "The Contribution of Income, Social Capital, and Institutions to Human Well-being in Africa," unpublished, University of Manchester (October 2004).

Besley, Timothy, and Robin Burgess, "Halving Global Poverty," Journal of Economic Perspectives, 17 (Summer 2003), 3-22.

Brenneman, Adam, and Michel Kerf, "Infrastructure and Poverty Linkages: A Literature Review," unpublished, the World Bank (December 2002).

Broca, Sumiter, and Kostas Stamoulis, "Micro- and Macroevidence on the Impact of Undernourishment," in Nutrition Intake and Economic Growth, ed. by Kiyoshi Taniguchi and Xiaojun Wang, Food and Agriculture Organization of the United Nations (Rome: 2003).

Bundy, Donald, and others, "School Health and Nutrition Programs," in Disease Control Priorities in Developing Countries, ed. by Dean Jamison and others, 2nd ed., forthcoming, Oxford University Press (New York: 2005).

Chakravarty, Satya, "A generalized Human Development Index," Review of Development Economics, 7 (March 2003), 99-114.

Christiansen, Luc, Lionel Demery, and Stefano Paternostro, "Macro and Micro Perspectives of Growth and Poverty in Africa," World Bank Economic Review, 17 (June 2003), 317-47.

Commission for Africa, Our Common Interest: Report of the Commission for Africa, Department of International Development, London (March 2005).

German Development Cooperation, "Making Poverty Reduction Strategies Work-Good Practices, Issues, and Stakeholder Views," unpublished, German Ministry for Economic Cooperation and Development (May 2005).

Millennium Project, Investing in Development: A Practical Plan to Achieve the Millennium Development Goals, Report to the United Nations Secretary General, New York (January 2005).

Nurkse, Ragnar, Problems of Capital Formation in Underdeveloped Countries, Oxford University Press (New York: 1953). 
OECD, "Role of Infrastructure in Economic Growth and Poverty Reduction: Lessons Learned from PRSPs of 33 Countries," DAC Network on Poverty Reduction, DCD/DAC/ POVNET(2004)16 (October 2004).

Pinto Moreira, Emmanuel, and Nihal Bayraktar, "A Macroeconomic Framework for Quantifying Growth and Poverty Reduction Strategies in Niger," revised, World Bank (September 2005).

Pritchett, Lant, "Mind your P's and Q's. The Cost of Public Investment is not the Value of Capital," Policy Research Working Paper No. 1660, World Bank (October 1996).

Rajan, Raghuram G., and Arvind Subramanian, "What undermines Aid's Impact on Growth?," Working Paper No. 05/126, International Monetary Fund (June 2005a).

- "Aid and Growth: What does the Cross-Country Evidence really Show?," Working Paper No. 05/127, International Monetary Fund (June 2005b).

Ravallion, Martin, "Pro-Poor Growth: A Primer," Policy Research Working Paper No. 3242, World Bank (March 2004).

Smith, Lisa C., and Lawrence Haddad, "Explaining Child Malnutrition in Developing Countries: A Cross-Country Analysis," Research Report No. 111, International Food Policy Research Institute (May 2000).

United Nations, The Millennium Development Goals Report 2005, United Nations (New York: 2005).

World Bank, Achieving the Millennium Development Goals in Africa: Progress, Prospects, and Policy Implications, Global Poverty Report 2002, World Bank (Washington DC: 2002).

- The Poverty Reduction Strategy Initiative: An Independent Evaluation of the World Bank's Support through 2003, Operations Evaluation Department, World Bank (Washington DC: 2004).

- Annual Review of Development Effectiveness 2004: The Bank's Contributions to Poverty Reduction, Operations Evaluation Department, World Bank (Washington DC: 2005a).

- Millennium Development Goals: From Consensus to Momentum, Global Monitoring Report 2005, World Bank (Washington DC: 2005b).

- Meeting the Challenge of Africa's Development: A World Bank Group Action Plan, Africa Region, World Bank (Washington DC: 2005c). 


\section{Appendix \\ Data and Cross-Section Regressions}

As described in the text, the focus of our macroeconomic approach is on six of the MDG indicators. Because the model can directly calculate values for the poverty and the literacy rates, we only ran regressions to estimate the equations for infant mortality, malnutrition, life expectancy, and access to safe water. The estimation method is ordinary least squares. We use cross-section data, obtained by taking average values of variables for each country for the period 1965-2003, depending on the availability of data series. Our sample consists of Sub-Saharan countries. This Appendix provides more detail about the data and the regressions.

The main data source of the regressions is World Development Indicators and World Bank African Database (unless otherwise specified). The following Sub-Saharan African countries are included in the sample ${ }^{19}$ : Angola, Benin, Botswana, Burkina Faso, Burundi, Cameroon, Cape Verde, Central African Republic, Chad, Comoros, Congo, Dem. Rep., Congo, Rep., Cote d'Ivoire, Equatorial Guinea, Eritrea, Ethiopia, Gabon, Gambia, Ghana, Guinea, GuineaBissau, Kenya, Lesotho, Liberia, Madagascar, Malawi, Mali, Mauritania, Mauritius, Mozambique, Namibia, Niger, Nigeria, Rwanda, Sao Tome and Principe, Senegal, Seychelles, Sierra Leone, Somalia, South Africa, Sudan, Swaziland, Tanzania, Togo, Uganda, Zambia, Zimbabwe. ${ }^{20}$ The time period is 1965 and 2003, depending on data availability.

Due to insufficient number of data points for sub-Saharan countries, all developing countries are included in the improved water source regressions, depending on data availability. The list of countries included in the "improved" water source regressions is: Argentina, Bolivia, Brazil, Bulgaria, Burkina Faso, Cameroon, Colombia, Cote d'Ivoire, Dominican Republic, Egypt, Ethiopia, Hungary, India, Indonesia, Iran, Madagascar, Maldives, Mauritius, Mexico, Morocco, Myanmar, Nepal, Nicaragua, Paraguay, Sri Lanka, Syria, Thailand, Tonga, Tunisia, Turkey, Vanuatu, and Yemen.

The list of variables and their definitions are as follows:

Malnutrition prevalence, weight for age (\% of children under 5): Prevalence of child malnutrition (weight for age) is the percentage of children under five whose weight for age is more than two standard deviations below the median reference standard for their age as established by the World Health Organization, the U.S. Centers for Disease Control and Prevention, and the U.S.

\footnotetext{
${ }^{19}$ The number of countries included in each regression changes, depending on data availability.

${ }^{20}$ The regression results are robust to excluding oil exporting countries and South Africa. The results obtained using this smaller dataset are presented in Table A2.
} 
National Center for Health Statistics. Figures are based on children under age three, four, and five years of age, depending on the country.

Mortality rate, infant (per 1,000 live births): Infant mortality rate is the number of infants dying before reaching one year of age, per 1,000 live births in a given year.

Life expectancy at birth, total (years): Life expectancy at birth indicates the number of years a newborn infant would live if prevailing patterns of mortality at the time of its birth were to stay the same throughout its life.

Improved water source (\% of population with access): Access to an improved water source refers to the percentage of the population with reasonable access to an adequate amount of water from an improved source, such as a household connection, public standpipe, borehole, protected well or spring, and rainwater collection. Unimproved sources include vendors, tanker trucks, and unprotected wells and springs. Reasonable access is defined as the availability of at least 20 liters a person a day from a source within one kilometer of the dwelling.

Public health expenditure in \% of GDP: Public health expenditure consists of recurrent and capital spending from government (central and local) budgets, external borrowings and grants (including donations from international agencies and nongovernmental organizations), and social (or compulsory) health insurance funds.

Public infrastructure expenditure in percent of GDP: Public infrastructure expenditure consists of energy, transportation, and communication. The data source is Government Financial Statistics.

Final private consumption expenditure in per capita terms (in constant 2003 U.S. dollars): Household final consumption expenditure (private consumption) is the market value of all goods and services, including durable products (such as cars, washing machines, and home computers), purchased by households. It excludes purchases of dwellings but includes imputed rent for owner-occupied dwellings. It also includes payments and fees to governments to obtain permits and licenses. Here, household consumption expenditure includes the expenditures of nonprofit institutions serving households, even when reported separately by the country.

GDP in per capita terms (in constant 2003 U.S. dollars): GDP is the sum of gross value added by all resident producers in the economy plus any product taxes and minus any subsidies not included in the value of the products. It is calculated without making deductions for depreciation of fabricated assets or for depletion and degradation of natural resources. 
Population density (people per sq km): Population density is midyear population divided by land area in square kilometers. Population is based on the de facto definition of population, which counts all residents regardless of legal status or citizenship--except for refugees not permanently settled in the country of asylum, who are generally considered part of the population of their country of origin. Land area is a country's total area, excluding area under inland water bodies, national claims to continental shelf, and exclusive economic zones. In most cases the definition of inland water bodies includes major rivers and lakes.

Poverty headcount ratio at national poverty line (\% of population): National poverty rate is the percentage of the population living below the national poverty line. National estimates are based on population-weighted sub-group estimates from household surveys.

Estimation results are shown in Tables A1 to A2.

We explain the malnutrition prevalence rate by public health expenditure in percent of GDP, real private consumption per capita, and poverty. The estimated coefficients of the first two variables have a negative sign and are statistically significant. This indicates that both public health expenditure and private consumption reduce the malnutrition prevalence rate. The coefficient of poverty is positive, which indicates that as poverty decreases, malnutrition prevalence falls as well.

Infant mortality is explained by public health expenditure, GDP per capita, and poverty. The estimated coefficients of public health expenditure and GDP per capita have a negative sign, which indicates that as they increase, infant mortality drops. The coefficient of poverty is positive and statistically significant. This indicates that as poverty drops, infant mortality decreases as well.

Life expectancy is explained by public health expenditure, GDP per capita, and poverty. The results indicate that both health expenditure and GDP per capita increase life expectancy. On the other hand, the coefficient of poverty is highly significant and negative, as expected. As poverty drops, life expectancy at birth increases.

The share of population with access to safe water is taken to be a function of population density, GDP per capita, and public infrastructure expenditure per capita. The sign of population density is positive as expected since the average cost of building infrastructure capital may drop with higher density; thus, the share of population with access to safe water increases. The coefficient of GDP per capita is positive as well. An increase in public infrastructure expenditure per capita leads to a rise in the share of population with access to safe water increases. 
Table A1

Cross-Section Regression Results

(All sub-Saharan countries are included unless otherwise indicated)

\begin{tabular}{|c|c|c|c|c|}
\hline & \multicolumn{4}{|c|}{ Dependent variables } \\
\hline \multirow[b]{2}{*}{ Constant term } & MALNUTRITION & In(MORTALITY) & In(LIFE_EXP) & WATER 2 I \\
\hline & $\begin{array}{l}75.415 \\
(6.055)\end{array}$ & $\begin{array}{l}5.485 \\
(10.761)\end{array}$ & $\begin{array}{l}3.428 \\
(27.187)\end{array}$ & $\begin{array}{l}6.711 \\
(0.299)\end{array}$ \\
\hline HEA_P_GDP $\underline{1} /$ & $\begin{array}{l}-4.790 \\
(-3.961)\end{array}$ & $\begin{array}{l}-0.091 \\
(-1.949)\end{array}$ & $\begin{array}{l}0.048 \\
(2.802)\end{array}$ & $\ldots$ \\
\hline $\ln (\mathrm{CPPC} 2003 \$)$ & $\begin{array}{l}-7.951 \\
(-4.126)\end{array}$ & $\ldots$ & $\ldots$ & $\cdots$ \\
\hline POVERTY & $\begin{array}{l}0.144 \\
(1.635)\end{array}$ & $\begin{array}{l}0.011 \\
(3.247)\end{array}$ & $\begin{array}{l}-0.002 \\
(-2.771)\end{array}$ & $\ldots$ \\
\hline In(GDPPC2003\$) & $\ldots$ & $\begin{array}{l}-0.191 \\
(-2.820)\end{array}$ & $\begin{array}{l}0.078 \\
(4.189)\end{array}$ & $\begin{array}{l}6.921 \\
(2.458)\end{array}$ \\
\hline INF_GDP & $\cdots$ & $\ldots$ & $\ldots$ & $\begin{array}{l}1.702 \\
(1.718)\end{array}$ \\
\hline In(POP_DENSITY) & $\cdots$ & $\cdots$ & $\cdots$ & $\begin{array}{l}4.076 \\
(1.551)\end{array}$ \\
\hline $\begin{array}{l}\text { Number of } \\
\text { observations }\end{array}$ & 28 & 31 & 20 & 31 \\
\hline Adjusted $\mathrm{R}^{2}$ & 0.552 & 0.479 & 0.739 & 0.292 \\
\hline
\end{tabular}

Note: The estimation technique is OLS. Data points of independent variables in each country correspond exactly to the years in which dependent variables are available. First, averages at the country level are calculated, then the regression equations are run using these cross sectional data. tstatistics are reported in parenthesis. MALNUTRITION is malnutrition prevalence, weight for age (\% of children under 5); HEA_P_GDP is public health expenditure in \% of GDP; CPPC2003\$ is private consumption per capita (in constant 2003 dollars); POVERTY is the percent of population living under $\$ 2$ per day; MORTALITY is infant mortality rate (per 1000 live births); GDPPC2003\$ is GDP per capita (in constant 2003 dollars); LIFE_EXP is life expectancy at birth, total, years; INF_GDP is public infrastructure expenditure in percent of GDP; WATER is percentage of population with access to safe water; POPDEN is population density (people per km square).

$1 /$ While the data source of public heath expenditure is Government Financial Statistics in the lifeexpectancy regression, the data source of public heath expenditure is World Bank African Database in other regressions.

2/ Due to insufficient number of data points for sub-Saharan African countries, all developing countries are included depending on data availability. 
Table A2

Cross-Section Regression Results

(Oil-exporting countries and South Africa are excluded)

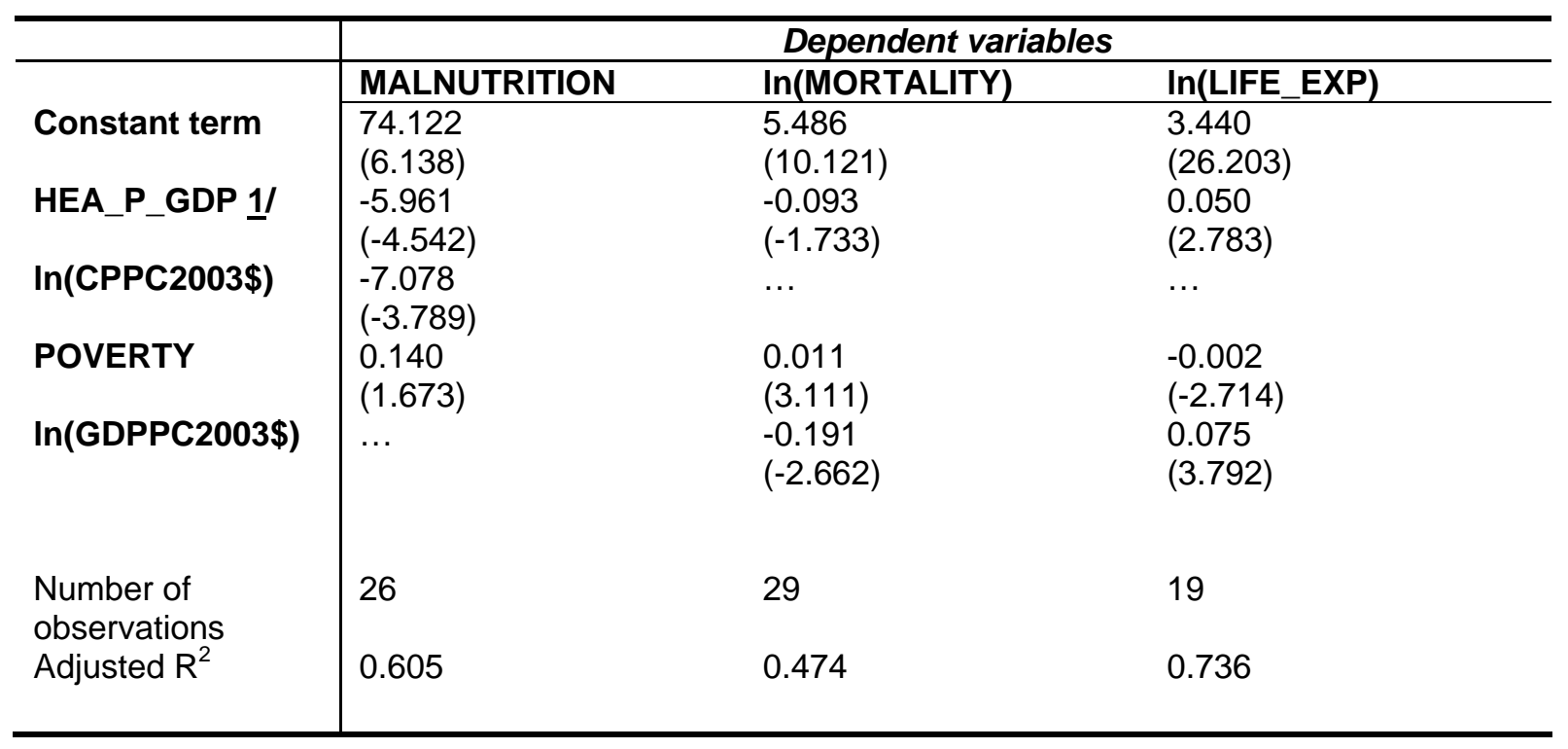

Note: The estimation technique is OLS. Data points of independent variables in each country correspond exactly to the years in which dependent variables are available. First, averages at the country level are calculated, then the regression equations are run using these cross sectional data. tstatistics are reported in parenthesis. MALNUTRITION is malnutrition prevalence, weight for age (\% of children under 5); HEA_P_GDP is public health expenditure in \% of GDP; CPPC2003\$ is private consumption per capita (in constant 2003 dollars); POVERTY is the percent of population living under \$2 per day; MORTALITY is infant mortality rate (per 1000 live births); GDPPC2003\$ is GDP per capita (in constant 2003 dollars); LIFE_EXP is life expectancy at birth, total, years.

$1 /$ While the data source of public heath expenditure is Government Financial Statistics in the lifeexpectancy regression, the data source of public heath expenditure is World Bank African Database in other regressions. 
Table 2

Niger: MDG Indicators, Baseline Results for 2005-15

\begin{tabular}{|c|c|c|c|c|c|c|c|c|c|c|c|c|}
\hline & \multirow[b]{2}{*}{1990} & \multicolumn{11}{|c|}{ Projections } \\
\hline & & 2005 & 2006 & 2007 & 2008 & 2009 & 2010 & 2011 & 2012 & 2013 & 2014 & 2015 \\
\hline $\begin{array}{l}\text { Poverty rate }(2003=63) \\
\text { (\% of the population living below } \$ 2 \text { per day) }\end{array}$ & $63.0 \underline{1} /$ & & & & & & & & & & & \\
\hline Consumption per capita growth elasticity of -0.5 & & 64.3 & 63.5 & 62.4 & 61.1 & 59.8 & 58.5 & 57.3 & 56.1 & 55.1 & 54.2 & 53.4 \\
\hline Consumption per capita growth elasticity of -1.0 & & 65.6 & 64.0 & 61.8 & 59.2 & 56.7 & 54.2 & 51.9 & 49.9 & 48.1 & 46.5 & 45.1 \\
\hline Consumption per capita growth elasticity of -1.5 & & 66.9 & 64.5 & 61.1 & 57.3 & 53.6 & 50.1 & 46.9 & 44.1 & 41.7 & 39.7 & 37.9 \\
\hline Ravallion's (2004) adjusted elasticity (Gini $=50.5)$ & & 65.9 & 64.2 & 61.6 & 58.8 & 55.8 & 53.1 & 50.6 & 48.3 & 46.3 & 44.6 & 43.1 \\
\hline $\begin{array}{l}\text { Literacy rate } \\
\text { (\% of educated labor in total population) }\end{array}$ & 11.4 & 19.2 & 19.9 & 20.8 & 21.7 & 22.6 & 23.5 & 24.4 & 25.3 & 26.1 & 26.9 & 27.6 \\
\hline $\begin{array}{l}\text { Infant mortality }(\mathbf{2 0 0 2}=\mathbf{1 5 5}) \\
\text { (Infant mortality rate per } 1000 \text { live births) }\end{array}$ & 191 & 156 & 153 & 149 & 144 & 139 & 135 & 131 & 127 & 124 & 121 & 119 \\
\hline $\begin{array}{l}\text { Malnutrition }(2000=40.1) \\
\text { (Malnutrition prevalence, weight for age) }\end{array}$ & $42.6 \underline{2}$ & 41.1 & 41.1 & 40.7 & 40.2 & 39.6 & 39.1 & 38.5 & 38.0 & 37.6 & 37.2 & 36.8 \\
\hline $\begin{array}{l}\text { Life expectancy }(2002=46.2) \\
\text { (Life expectancy at birth, years ) }\end{array}$ & 42.1 & 46.5 & 46.5 & 46.8 & 47.1 & 47.5 & 47.8 & 48.1 & 48.4 & 48.6 & 48.9 & 49.1 \\
\hline $\begin{array}{l}\text { Access to safe water }(2000=59) \\
\text { (Percentage of population with access to safe water) }\end{array}$ & 53.0 & 57.5 & 57.9 & 58.3 & 58.7 & 59.1 & 59.6 & 60.0 & 60.3 & 60.7 & 61.1 & 61.4 \\
\hline $\begin{array}{l}\text { COMPOSITE MDG INDICATOR }(2005=100) \\
\text { (A rise denotes an improvement) }\end{array}$ & & 100.0 & 101.4 & 103.7 & 106.2 & 108.9 & 111.5 & 114.1 & 116.6 & 118.9 & 121.0 & 123.0 \\
\hline \multicolumn{13}{|l|}{ Aid and external debt indicators } \\
\hline Foreign aid (in \% of GDP) & & 10.7 & 10.7 & 10.7 & 10.7 & 10.7 & 10.7 & 10.7 & 10.7 & 10.7 & 10.7 & 10.7 \\
\hline Aid (in \% of total government revenue) & & 51.4 & 51.4 & 51.3 & 51.3 & 51.2 & 51.2 & 51.1 & 51.0 & 50.9 & 50.8 & 50.8 \\
\hline External debt (in \% of GDP) & & 62.0 & 59.4 & 56.4 & 53.3 & 50.5 & 48.1 & 46.0 & 44.2 & 42.7 & 41.4 & 40.4 \\
\hline Interest payments on external public debt (in \% of GDP) & & 0.5 & 0.5 & 0.5 & 0.5 & 0.4 & 0.4 & 0.4 & 0.4 & 0.4 & 0.4 & 0.3 \\
\hline Interest payments on external public debt (in \% of exports) & & 3.6 & 3.4 & 3.2 & 3.0 & 2.9 & 2.8 & 2.7 & 2.6 & 2.5 & 2.4 & 2.3 \\
\hline
\end{tabular}

Note: The "adjusted" elasticity formula proposed by Ravallion (2004) is $-9.3^{\star}(1-$ Gini)^3 $=-1.13$ where Gini index is 50.5 for Niger.

Malnutrition prevalence is in \% of children under 5 .

$1 /$ The observation year is 1993 .

2/ The observation year is 1992 
Table 4

Niger: External Debt Cancellation in 2006, Simulation Results for 2006-15

(Absolute deviations from baseline)

\begin{tabular}{|c|c|c|c|c|c|c|c|c|c|c|}
\hline & \multicolumn{10}{|c|}{ Projections } \\
\hline & 2006 & 2007 & 2008 & 2009 & 2010 & 2011 & 2012 & 2013 & 2014 & 2015 \\
\hline \multicolumn{11}{|l|}{$\begin{array}{l}\text { Poverty rate }(2003=63) \\
\text { (\% of the population living below } \$ 2 \text { per day) }\end{array}$} \\
\hline Consumption per capita growth elasticity of -0.5 & 0.0 & -0.1 & -0.1 & -0.2 & -0.2 & -0.3 & -0.4 & -0.4 & -0.5 & -0.5 \\
\hline Consumption per capita growth elasticity of -1.0 & -0.1 & -0.1 & -0.2 & -0.3 & -0.4 & -0.5 & -0.7 & -0.8 & -0.9 & -0.9 \\
\hline Consumption per capita growth elasticity of -1.5 & -0.1 & -0.2 & -0.3 & -0.4 & -0.6 & -0.8 & -0.9 & -1.0 & -1.1 & -1.2 \\
\hline Ravallion's (2004) adjusted elasticity (Gini = 50.5) & -0.1 & -0.1 & -0.2 & -0.3 & -0.5 & -0.6 & -0.7 & -0.8 & -0.9 & -1.0 \\
\hline $\begin{array}{l}\text { Literacy rate } \\
\text { (\% of educated labor in total population) }\end{array}$ & 0.0 & 0.0 & 0.0 & 0.1 & 0.1 & 0.2 & 0.3 & 0.3 & 0.4 & 0.5 \\
\hline $\begin{array}{l}\text { Infant mortality }(\mathbf{2 0 0 2}=\mathbf{1 5 5}) \\
\text { (Infant mortality rate per } 1000 \text { live births) }\end{array}$ & -2 & -1 & -1 & -2 & -2 & -2 & -2 & -2 & -2 & -2 \\
\hline $\begin{array}{l}\text { Malnutrition }(2000=40.1) \\
\text { (Malnutrition prevalence, weight for age) }\end{array}$ & -0.4 & -0.4 & -0.4 & -0.4 & -0.4 & -0.4 & -0.4 & -0.4 & -0.5 & -0.5 \\
\hline $\begin{array}{l}\text { Life expectancy }(2002=46.2) \\
\text { (Life expectancy at birth, years ) }\end{array}$ & 0.2 & 0.2 & 0.2 & 0.2 & 0.2 & 0.2 & 0.2 & 0.2 & 0.3 & 0.3 \\
\hline $\begin{array}{l}\text { Access to safe water }(2000=59) \\
\text { (Percentage of population with access to safe water) }\end{array}$ & 0.1 & 0.0 & 0.1 & 0.1 & 0.1 & 0.1 & 0.1 & 0.1 & 0.1 & 0.1 \\
\hline $\begin{array}{l}\text { COMPOSITE MDG INDICATOR } \\
\text { (A rise denotes an improvement) }\end{array}$ & 0.5 & 0.5 & 0.5 & 0.6 & 0.8 & 0.9 & 1.1 & 1.3 & 1.4 & 1.6 \\
\hline \multicolumn{11}{|l|}{ Aid and external debt indicators } \\
\hline Foreign aid (in \% of GDP) & 0.0 & 0.0 & 0.0 & 0.0 & 0.0 & 0.0 & 0.0 & 0.0 & 0.0 & 0.0 \\
\hline Aid (in \% of total government revenue) & 0.1 & 0.1 & 0.1 & 0.1 & 0.1 & 0.1 & 0.1 & 0.1 & 0.1 & 0.1 \\
\hline External debt (in \% of GDP) & -49.8 & -44.5 & -39.5 & -35.2 & -31.5 & -28.3 & -25.7 & -23.4 & -21.5 & -19.8 \\
\hline Interest payments on external public debt (in \% of GDP) & -0.5 & -0.5 & -0.4 & -0.4 & -0.3 & -0.3 & -0.3 & -0.2 & -0.2 & -0.2 \\
\hline Interest payments on external public debt (in \% of exports) & -3.4 & -3.0 & -2.7 & -2.4 & -2.2 & -2.0 & -1.8 & -1.6 & -1.5 & -1.4 \\
\hline
\end{tabular}


Table 4

Niger: External Debt Cancellation in 2006, Simulation Results for 2006-15

(Absolute deviations from baseline)

\begin{tabular}{|c|c|c|c|c|c|c|c|c|c|c|}
\hline & \multicolumn{10}{|c|}{ Projections } \\
\hline & 2006 & 2007 & 2008 & 2009 & 2010 & 2011 & 2012 & 2013 & 2014 & 2015 \\
\hline \multicolumn{11}{|l|}{$\begin{array}{l}\text { Poverty rate }(2003=63) \\
\text { (\% of the population living below } \$ 2 \text { per day) }\end{array}$} \\
\hline Consumption per capita growth elasticity of -0.5 & 0.0 & -0.1 & -0.1 & -0.2 & -0.2 & -0.3 & -0.4 & -0.4 & -0.5 & -0.5 \\
\hline Consumption per capita growth elasticity of -1.0 & -0.1 & -0.1 & -0.2 & -0.3 & -0.4 & -0.5 & -0.7 & -0.8 & -0.9 & -0.9 \\
\hline Consumption per capita growth elasticity of -1.5 & -0.1 & -0.2 & -0.3 & -0.4 & -0.6 & -0.8 & -0.9 & -1.0 & -1.1 & -1.2 \\
\hline Ravallion's (2004) adjusted elasticity (Gini = 50.5) & -0.1 & -0.1 & -0.2 & -0.3 & -0.5 & -0.6 & -0.7 & -0.8 & -0.9 & -1.0 \\
\hline $\begin{array}{l}\text { Literacy rate } \\
\text { (\% of educated labor in total population) }\end{array}$ & 0.0 & 0.0 & 0.0 & 0.1 & 0.1 & 0.2 & 0.3 & 0.3 & 0.4 & 0.5 \\
\hline $\begin{array}{l}\text { Infant mortality }(\mathbf{2 0 0 2}=\mathbf{1 5 5}) \\
\text { (Infant mortality rate per } 1000 \text { live births) }\end{array}$ & -2 & -1 & -1 & -2 & -2 & -2 & -2 & -2 & -2 & -2 \\
\hline $\begin{array}{l}\text { Malnutrition }(2000=40.1) \\
\text { (Malnutrition prevalence, weight for age) }\end{array}$ & -0.4 & -0.4 & -0.4 & -0.4 & -0.4 & -0.4 & -0.4 & -0.4 & -0.5 & -0.5 \\
\hline $\begin{array}{l}\text { Life expectancy }(2002=46.2) \\
\text { (Life expectancy at birth, years ) }\end{array}$ & 0.2 & 0.2 & 0.2 & 0.2 & 0.2 & 0.2 & 0.2 & 0.2 & 0.3 & 0.3 \\
\hline $\begin{array}{l}\text { Access to safe water }(2000=59) \\
\text { (Percentage of population with access to safe water) }\end{array}$ & 0.1 & 0.0 & 0.1 & 0.1 & 0.1 & 0.1 & 0.1 & 0.1 & 0.1 & 0.1 \\
\hline $\begin{array}{l}\text { COMPOSITE MDG INDICATOR } \\
\text { (A rise denotes an improvement) }\end{array}$ & 0.5 & 0.5 & 0.5 & 0.6 & 0.8 & 0.9 & 1.1 & 1.3 & 1.4 & 1.6 \\
\hline \multicolumn{11}{|l|}{ Aid and external debt indicators } \\
\hline Foreign aid (in \% of GDP) & 0.0 & 0.0 & 0.0 & 0.0 & 0.0 & 0.0 & 0.0 & 0.0 & 0.0 & 0.0 \\
\hline Aid (in \% of total government revenue) & 0.1 & 0.1 & 0.1 & 0.1 & 0.1 & 0.1 & 0.1 & 0.1 & 0.1 & 0.1 \\
\hline External debt (in \% of GDP) & -49.8 & -44.5 & -39.5 & -35.2 & -31.5 & -28.3 & -25.7 & -23.4 & -21.5 & -19.8 \\
\hline Interest payments on external public debt (in \% of GDP) & -0.5 & -0.5 & -0.4 & -0.4 & -0.3 & -0.3 & -0.3 & -0.2 & -0.2 & -0.2 \\
\hline Interest payments on external public debt (in \% of exports) & -3.4 & -3.0 & -2.7 & -2.4 & -2.2 & -2.0 & -1.8 & -1.6 & -1.5 & -1.4 \\
\hline
\end{tabular}


Table 5

Niger: MDG Indicators, Baseline Results for 2005-15, Lower Efficiency of Public Investment

\begin{tabular}{|c|c|c|c|c|c|c|c|c|c|c|c|c|}
\hline & \multirow[b]{2}{*}{1990} & \multicolumn{11}{|c|}{ Projections } \\
\hline & & 2005 & 2006 & 2007 & 2008 & 2009 & 2010 & 2011 & 2012 & 2013 & 2014 & 2015 \\
\hline $\begin{array}{l}\text { Poverty rate }(2003=63) \\
\text { (\% of the population living below } \$ 2 \text { per day) }\end{array}$ & $63.0 \underline{1} /$ & & & & & & & & & & & \\
\hline Consumption per capita growth elasticity of -0.5 & & 64.3 & 63.7 & 62.9 & 62.0 & 61.1 & 60.4 & 59.6 & 59.0 & 58.4 & 57.9 & 57.5 \\
\hline Consumption per capita growth elasticity of -1.0 & & 65.6 & 64.3 & 62.7 & 61.0 & 59.3 & 57.7 & 56.4 & 55.1 & 54.1 & 53.2 & 52.4 \\
\hline Consumption per capita growth elasticity of -1.5 & & 66.9 & 65.0 & 62.5 & 59.9 & 57.4 & 55.1 & 53.2 & 51.5 & 50.0 & 48.7 & 47.7 \\
\hline Ravallion's (2004) adjusted elasticity (Gini $=50.5)$ & & 65.9 & 64.5 & 62.7 & 60.7 & 58.8 & 57.1 & 55.5 & 54.2 & 53.0 & 52.0 & 51.2 \\
\hline $\begin{array}{l}\text { Literacy rate } \\
\text { (\% of educated labor in total population) }\end{array}$ & 11.4 & 19.2 & 19.8 & 20.4 & 21.0 & 21.5 & 22.0 & 22.5 & 22.9 & 23.3 & 23.6 & 23.9 \\
\hline $\begin{array}{l}\text { Infant mortality }(\mathbf{2 0 0 2}=\mathbf{1 5 5}) \\
\text { (Infant mortality rate per } 1000 \text { live births) }\end{array}$ & 191 & 156 & 154 & 151 & 147 & 144 & 141 & 139 & 137 & 135 & 133 & 132 \\
\hline $\begin{array}{l}\text { Malnutrition }(2000=40.1) \\
\text { (Malnutrition prevalence, weight for age) }\end{array}$ & $42.6 \underline{2}$ & 41.1 & 41.2 & 40.9 & 40.5 & 40.2 & 39.8 & 39.5 & 39.3 & 39.0 & 38.8 & 38.7 \\
\hline $\begin{array}{l}\text { Life expectancy }(2002=46.2) \\
\text { (Life expectancy at birth, years ) }\end{array}$ & 42.1 & 46.5 & 46.5 & 46.7 & 46.9 & 47.1 & 47.3 & 47.5 & 47.6 & 47.8 & 47.9 & 48.0 \\
\hline $\begin{array}{l}\text { Access to safe water }(2000=59) \\
\text { (Percentage of population with access to safe water) }\end{array}$ & 53.0 & 57.5 & 57.8 & 58.1 & 58.5 & 58.8 & 59.1 & 59.4 & 59.6 & 59.9 & 60.1 & 60.3 \\
\hline $\begin{array}{l}\text { COMPOSITE MDG INDICATOR }(2005=100) \\
\text { (A rise denotes an improvement) }\end{array}$ & & 100.0 & 101.1 & 102.7 & 104.4 & 106.1 & 107.6 & 109.0 & 110.3 & 111.5 & 112.5 & 113.4 \\
\hline \multicolumn{13}{|l|}{ Aid and external debt indicators } \\
\hline Foreign aid (in \% of GDP) & & 10.7 & 10.7 & 10.7 & 10.7 & 10.7 & 10.7 & 10.7 & 10.7 & 10.7 & 10.7 & 10.7 \\
\hline Aid (in \% of total government revenue) & & 51.4 & 51.3 & 51.1 & 51.0 & 50.9 & 50.7 & 50.6 & 50.6 & 50.5 & 50.5 & 50.4 \\
\hline External debt (in \% of GDP) & & 62.2 & 60.1 & 57.8 & 55.6 & 53.5 & 51.8 & 50.2 & 48.9 & 47.8 & 46.7 & 45.8 \\
\hline Interest payments on external public debt (in \% of GDP) & & 0.5 & 0.5 & 0.5 & 0.5 & 0.5 & 0.4 & 0.4 & 0.4 & 0.4 & 0.4 & 0.4 \\
\hline Interest payments on external public debt (in \% of exports) & & 3.6 & 3.4 & 3.3 & 3.2 & 3.0 & 2.9 & 2.9 & 2.8 & 2.7 & 2.6 & 2.6 \\
\hline
\end{tabular}

Note: The "adjusted" elasticity formula proposed by Ravallion (2004) is $-9.3^{\star}(1-$ Gini)^3 $=-1.13$ where Gini index is 50.5 for Niger.

Malnutrition prevalence is in $\%$ of children under 5 .

$1 /$ The observation year is 1993.

2/ The observation year is 1992 
Table 6

Niger: 5 Percentage Point Increase in Aid-to-GDP Ratio, Simulation Results for 2006-15, Lower Efficiency of Public Investment (Absolute deviations from baseline)

\begin{tabular}{|c|c|c|c|c|c|c|c|c|c|c|}
\hline & \multicolumn{10}{|c|}{ Projections } \\
\hline & 2006 & 2007 & 2008 & 2009 & 2010 & 2011 & 2012 & 2013 & 2014 & 2015 \\
\hline \multicolumn{11}{|l|}{$\begin{array}{l}\text { Poverty rate }(2003=63) \\
\text { (\% of the population living below } \$ 2 \text { per day) }\end{array}$} \\
\hline Consumption per capita growth elasticity of -0.5 & -0.3 & -0.5 & -0.8 & -1.1 & -1.4 & -1.8 & -2.2 & -2.6 & -3.0 & -3.3 \\
\hline Consumption per capita growth elasticity of -1.0 & -0.6 & -1.0 & -1.5 & -2.1 & -2.7 & -3.4 & -4.1 & -4.7 & -5.4 & -6.0 \\
\hline Consumption per capita growth elasticity of -1.5 & -0.9 & -1.6 & -2.3 & -3.1 & -3.9 & -4.8 & -5.7 & -6.5 & -7.3 & -8.0 \\
\hline Ravallion's (2004) adjusted elasticity (Gini $=50.5)$ & -0.7 & -1.2 & -1.7 & -2.4 & -3.1 & -3.8 & -4.5 & -5.2 & -5.9 & -6.6 \\
\hline $\begin{array}{l}\text { Literacy rate } \\
\text { (\% of educated labor in total population) }\end{array}$ & 0.0 & 0.0 & 0.1 & 0.3 & 0.5 & 0.7 & 1.0 & 1.3 & 1.6 & 2.0 \\
\hline $\begin{array}{l}\text { Infant mortality (2002=155) } \\
\text { (Infant mortality rate per } 1000 \text { live births) }\end{array}$ & -10 & -10 & -11 & -11 & -12 & -13 & -14 & -15 & -16 & -17 \\
\hline $\begin{array}{l}\text { Malnutrition }(2000=40.1) \\
\text { (Malnutrition prevalence, weight for age) }\end{array}$ & -3.0 & -2.8 & -2.9 & -3.0 & -3.2 & -3.3 & -3.5 & -3.7 & -3.9 & -4.1 \\
\hline $\begin{array}{l}\text { Life expectancy }(2002=46.2) \\
\text { (Life expectancy at birth, years ) }\end{array}$ & 1.6 & 1.5 & 1.5 & 1.6 & 1.7 & 1.8 & 1.9 & 2.0 & 2.1 & 2.2 \\
\hline $\begin{array}{l}\text { Access to safe water }(2000=59) \\
\text { (Percentage of population with access to safe water) }\end{array}$ & 0.4 & 0.4 & 0.4 & 0.5 & 0.5 & 0.6 & 0.7 & 0.8 & 0.8 & 0.9 \\
\hline $\begin{array}{l}\text { COMPOSITE MDG INDICATOR } \\
\text { (A rise denotes an improvement) }\end{array}$ & 3.3 & 3.4 & 3.9 & 4.5 & 5.3 & 6.1 & 7.1 & 8.0 & 9.0 & 10.0 \\
\hline \multicolumn{11}{|l|}{ Aid and external debt indicators } \\
\hline Foreign aid (in \% of GDP) & 5.0 & 5.0 & 5.0 & 5.0 & 5.0 & 5.0 & 5.0 & 5.0 & 5.0 & 5.0 \\
\hline Aid (in $\%$ of total government revenue) & 10.6 & 10.8 & 10.9 & 11.1 & 11.2 & 11.2 & 11.3 & 11.3 & 11.3 & 11.3 \\
\hline External debt (in \% of GDP) & -5.7 & -8.0 & -10.2 & -12.1 & -13.8 & -15.3 & -16.6 & -17.8 & -18.9 & -19.9 \\
\hline Interest payments on external public debt (in \% of GDP) & 0.0 & -0.1 & -0.1 & -0.1 & -0.1 & -0.1 & -0.1 & -0.2 & -0.2 & -0.2 \\
\hline Interest payments on external public debt (in \% of exports) & 0.0 & -0.1 & -0.2 & -0.3 & -0.4 & -0.5 & -0.6 & -0.6 & -0.7 & -0.8 \\
\hline
\end{tabular}


Table 7

Niger: External Debt Cancellation in 2006, Simulation Results for 2006-15, Lower Efficiency of Public Investment

(Absolute deviations from baseline)

\begin{tabular}{|c|c|c|c|c|c|c|c|c|c|c|}
\hline & \multicolumn{10}{|c|}{ Projections } \\
\hline & 2006 & 2007 & 2008 & 2009 & 2010 & 2011 & 2012 & 2013 & 2014 & 2015 \\
\hline \multicolumn{11}{|l|}{$\begin{array}{l}\text { Poverty rate }(2003=63) \\
\text { (\% of the population living below } \$ 2 \text { per day) }\end{array}$} \\
\hline Consumption per capita growth elasticity of -0.5 & 0.0 & -0.1 & -0.1 & -0.1 & -0.2 & -0.2 & -0.3 & -0.3 & -0.4 & -0.4 \\
\hline Consumption per capita growth elasticity of -1.0 & -0.1 & -0.1 & -0.2 & -0.3 & -0.3 & -0.4 & -0.5 & -0.6 & -0.7 & -0.7 \\
\hline Consumption per capita growth elasticity of -1.5 & -0.1 & -0.2 & -0.3 & -0.4 & -0.5 & -0.6 & -0.7 & -0.8 & -0.9 & -1.0 \\
\hline Ravallion's (2004) adjusted elasticity (Gini $=50.5$ ) & -0.1 & -0.1 & -0.2 & -0.3 & -0.4 & -0.5 & -0.6 & -0.7 & -0.7 & -0.8 \\
\hline $\begin{array}{l}\text { Literacy rate } \\
\text { (\% of educated labor in total population) }\end{array}$ & 0.0 & 0.0 & 0.0 & 0.0 & 0.1 & 0.1 & 0.1 & 0.2 & 0.2 & 0.3 \\
\hline $\begin{array}{l}\text { Infant mortality }(\mathbf{2 0 0 2}=\mathbf{1 5 5}) \\
\text { (Infant mortality rate per } 1000 \text { live births) }\end{array}$ & -2 & -1 & -1 & -1 & -2 & -2 & -2 & -2 & -2 & -2 \\
\hline $\begin{array}{l}\text { Malnutrition }(2000=40.1) \\
\text { (Malnutrition prevalence, weight for age) }\end{array}$ & -0.4 & -0.4 & -0.4 & -0.4 & -0.4 & -0.4 & -0.4 & -0.4 & -0.4 & -0.4 \\
\hline $\begin{array}{l}\text { Life expectancy }(2002=46.2) \\
\text { (Life expectancy at birth, years })\end{array}$ & 0.2 & 0.2 & 0.2 & 0.2 & 0.2 & 0.2 & 0.2 & 0.2 & 0.2 & 0.2 \\
\hline $\begin{array}{l}\text { Access to safe water }(2000=59) \\
\text { (Percentage of population with access to safe water) }\end{array}$ & 0.1 & 0.0 & 0.1 & 0.1 & 0.1 & 0.1 & 0.1 & 0.1 & 0.1 & 0.1 \\
\hline $\begin{array}{l}\text { COMPOSITE MDG INDICATOR } \\
\text { (A rise denotes an improvement) }\end{array}$ & 0.5 & 0.5 & 0.5 & 0.6 & 0.6 & 0.7 & 0.8 & 0.9 & 1.0 & 1.1 \\
\hline \multicolumn{11}{|l|}{ Aid and external debt indicators } \\
\hline Foreign aid (in \% of GDP) & 0.0 & 0.0 & 0.0 & 0.0 & 0.0 & 0.0 & 0.0 & 0.0 & 0.0 & 0.0 \\
\hline Aid (in $\%$ of total government revenue) & 0.1 & 0.1 & 0.1 & 0.1 & 0.1 & 0.1 & 0.1 & 0.1 & 0.1 & 0.1 \\
\hline External debt (in \% of GDP) & -50.6 & -45.9 & -41.7 & -38.1 & -34.9 & -32.2 & -29.9 & -27.8 & -26.0 & -24.4 \\
\hline Interest payments on external public debt (in \% of GDP) & -0.5 & -0.5 & -0.4 & -0.4 & -0.4 & -0.3 & -0.3 & -0.3 & -0.3 & -0.3 \\
\hline Interest payments on external public debt (in \% of exports) & -3.4 & -3.1 & -2.8 & -2.6 & -2.4 & -2.2 & -2.0 & -1.9 & -1.7 & -1.6 \\
\hline
\end{tabular}

